\title{
The Twilight Zone as a Major Foraging Habitat and Mercury Source for the Great White Shark
}

\author{
Le Croizier Gaël 1, ${ }^{*}$, Lorrain Anne ${ }^{2}$, Sonke Jeroen E. ${ }^{1}$, Hoyos-Padilla E. Mauricio 3, 4, , \\ Galván-Magaña Felipe ${ }^{5}$, Santana-Morales Omar ${ }^{6}$, Aquino-Baleytó Marc ${ }^{3,5}$, \\ Becerril-García Edgar E. 3, 5, Muntaner-López Gádor 3, 5, Ketchum James ${ }^{3}$, Block Barbara 7 , \\ Carlisle Aaron ${ }^{8}$, Jorgensen Salvador J. ${ }^{9}$, Besnard Lucien ${ }^{2}$, Jung Armelle ${ }^{10}$, Schaal Gauthier ${ }^{2}$, \\ Point David ${ }^{1}$
}

${ }^{1}$ UMR Géosciences Environnement Toulouse (GET), Observatoire Midi Pyrénées (OMP), 14 avenue Edouard Belin, 31400 Toulouse, France

2 Univ Brest, CNRS, Ifremer, LEMAR, 29280 Plouzané, France

3 Pelagios-Kakunjá A.C., Sinaloa 1540, Col. Las Garzas, 23070 La Paz, Baja California Sur, México

${ }^{4}$ Fins Attached: Marine Research and Conservation, 19675 Still Glen Drive, Colorado Springs, Colorado 80908, United States

${ }^{5}$ Instituto Politécnico Nacional, Centro Interdisciplinario de Ciencias Marinas, Av. IPN s/n., 23096 La

Paz, Baja California Sur, México

${ }^{6}$ ECOCIMATI A.C., 22800 Ensenada, Baja California, Mexico

${ }^{7}$ Hopkins Marine Station, Stanford University, Pacific Grove, California 93950, United States

${ }^{8}$ School of Marine Science and Policy, University of Delaware, Lewes, Delaware 19958, United States

9 Institute of Marine Sciences, University of California, Santa Cruz, Santa Cruz, California 95064, United States

10 Des Requins et Des Hommes (DRDH), BLP/Technopole Brest-Iroise, 15 rue Dumont d'Urville, Plouzané 29860, France

*Corresponding authors: Gaël Le Croizier, email address : gael.lecroizier@hotmail.fr ; Mauricio E. Hoyos Padilla, amuakua@gmail.com

\begin{abstract}
The twilight zone contains the largest biomass of the world's ocean. Identifying its role in the trophic supply and contaminant exposure of marine megafauna constitutes a critical challenge in the context of global change. The white shark (Carcharodon carcharias) is a threatened species with some of the highest concentrations of neurotoxin methylmercury $(\mathrm{MeHg})$ among marine top predators. Large white sharks migrate seasonally from coastal habitats, where they primarily forage on pinnipeds, to oceanic offshore habitats. Tagging studies suggest that while offshore, white sharks may forage at depth on mesopelagic species, yet no biochemical evidence exists. Here, we used mercury isotopic composition to assess the dietary origin of $\mathrm{MeHg}$ contamination in white sharks from the Northeast Pacific Ocean. We estimated that a minimum of $72 \%$ of the $\mathrm{MeHg}$ accumulated by white sharks originates from the consumption of mesopelagic prey, while a maximum of $25 \%$ derives from pinnipeds. In addition to highlighting the potential of mercury isotopes to decipher the complex ecological cycle of marine predators, our study provides evidence that the twilight zone constitutes a crucial foraging habitat for these large predators,
\end{abstract}


which had been suspected for over a decade. Climate change is predicted to expand the production of mesopelagic $\mathrm{MeHg}$ and modify the mesopelagic biomass globally. Considering the pivotal role of the twilight zone is therefore essential to better predict both $\mathrm{MeHg}$ exposure and trophic supply to white sharks, and effectively protect these key vulnerable predators.

\section{Graphical abstract}

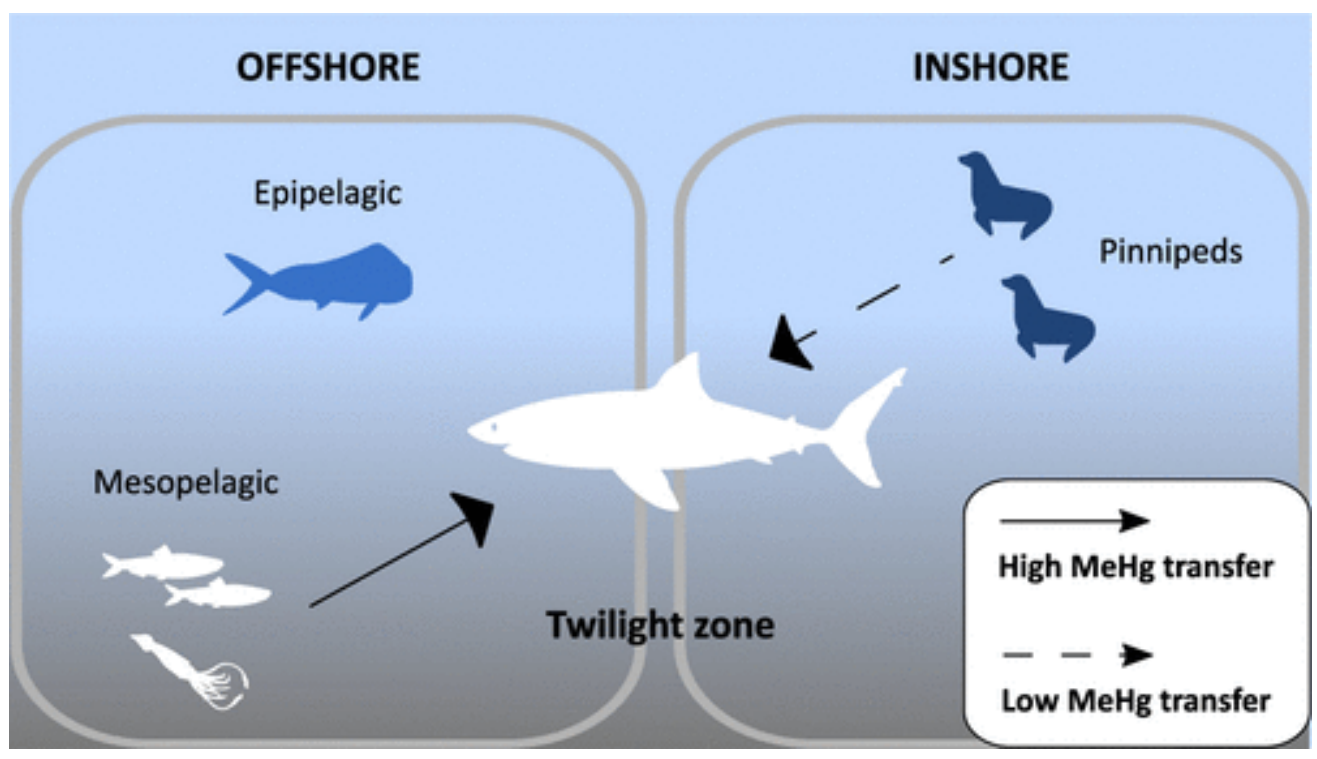




\section{Introduction}

Many shark populations are declining worldwide in the Anthropocene ${ }^{1-3}$, with potential large-scale cascading effects such as changes in abundance, distribution and behavior of prey, that may impact the structure and function of marine ecosystems ${ }^{4-6}$. As an apex predator, the white shark (Carcharodon carcharias) is a key species that exists in low abundance, implying low capacity for population recovery ${ }^{7,8}$. Consequently, white sharks are particularly vulnerable to extinction, along with their ecosystem role as apex predators ${ }^{6}$. As white sharks experience different levels of protection during their migrations (e.g. areas within and beyond national jurisdictions) ${ }^{9}$, understanding more about how they use ocean ecosystems is vital to their protection.

Mercury $(\mathrm{Hg})$ is a global pollutant of both anthropogenic and natural origin, of which $80 \%$ of atmospheric emissions are deposited in the ocean ${ }^{10}$. Once in seawater, a fraction of deposited inorganic $\mathrm{Hg}$ is converted trough microbial activity to toxic methylmercury (MeHg) ${ }^{11}$, which is bioaccumulated by aquatic organisms and biomagnified along trophic webs. Due to their long lifespans and high trophic positions, apex predators are particularly prone to MeHg contamination, potentially causing adverse effects on their reproduction, development, behavior and nervous system function ${ }^{12-14}$. Although the impact of $\mathrm{MeHg}$ exposure on shark neurophysiology is still poorly understood ${ }^{15}$, white sharks display some of the highest MeHg concentrations among shark species ${ }^{16}$. MeHg accumulation in white sharks may thus exceed neurotoxicity thresholds proposed for other marine predators ${ }^{13,14}$ and potentially pose an additional threat to this vulnerable species.

Large white sharks are known to aggregate near coastal seal colonies across the global oceans ${ }^{17}$. In the Northeastern Pacific, reproductively mature individuals migrate 
seasonally from aggregation areas in the productive ecosystem of the California Current (e.g. Guadalupe Island in Mexico and Central California in the USA) ${ }^{18}$, to oceanic habitats in the oligotrophic waters of the North Pacific Gyre ${ }^{19,20}$. While the hunting behavior of white sharks on seals in coastal environments has been widely documented ${ }^{21-23}$, little is known about their feeding ecology in the open ocean ${ }^{24,25}$. Recently, offshore movements of blue and white sharks in the Atlantic Ocean have been linked to oceanic processes and more particularly to mesoscale eddies ${ }^{26,27}$. The vertical mixing dynamics associated with these structures may facilitate access to deep mesopelagic prey. In the Northeast Pacific Ocean, tagging studies revealed that white sharks perform offshore dives in the mesopelagic zone 20,28. Foraging in these depths, also called the twilight zone (i.e. between 200 and $1000 \mathrm{~m}$ deep), enables access to the largest fish biomass in the global ocean ${ }^{29}$. Despite the growing number of studies suggesting that it constitutes a crucial foraging habitat for large pelagic predators, no direct evidence of deep water feeding by white sharks has been provided to date in the Northeastern Pacific.

As $\mathrm{MeHg}$ production by bacterial transformation is enhanced in deep low oxygen waters ${ }^{30}, \mathrm{MeHg}$ exposure increases with foraging depth in pelagic consumers at both the interspecific ${ }^{31}$ and intraspecific scale ${ }^{32,33}$, when feeding on mesopelagic prey ${ }^{34}$. Pinnipeds, such as the northern elephant seal (Mirounga angustirostris) targeted by white sharks in the Northeastern Pacific, are predators themselves and can display high MeHg concentrations ${ }^{33,35}$, generally exceeding MeHg levels in pelagic fish, squid ${ }^{36,37}$, and other mesopelagic prey 38. The high MeHg concentrations found both in pinnipeds and in potential offshore prey raise the question of the relative $\mathrm{MeHg}$ exposure associated with different prey, and different foraging depths, during the migratory cycle of white sharks between inshore and offshore habitats. 
dependent isotope fractionation (MDF, reported as $\delta^{202} \mathrm{Hg}$ ) and unique photochemical massindependent fractionation (MIF, reported as $\Delta^{199} \mathrm{Hg}$ ). These properties enable tracing $\mathrm{MeHg}$ sources in marine environments ${ }^{39-41}$. While Hg MDF is the result of various abiotic (e.g. photoreduction, volatilization) ${ }^{42,43}$ and biotic processes (e.g. methylation, demethylation) ${ }^{44-}$ ${ }^{46}, \mathrm{Hg}$ MIF occurs predominantly during photochemical reactions ${ }^{42}$. In seawater, solar radiations induce a MIF gradient from the surface to depths, which leads to higher $\Delta^{199} \mathrm{Hg}$ values in the photic or epipelagic zone (between 0 and $200 \mathrm{~m}$ deep) than in the twilight or mesopelagic zone (between 200 and 1000 m deep) where light penetration varies from weak to zero ${ }^{30,47}$. Thus, $\Delta^{199} \mathrm{Hg}$ values constitute a powerful tool to trace the feeding depth of marine predators, for instance discriminating epipelagic from mesopelagic foraging habitats 32,46. Importantly, $\Delta^{199} \mathrm{Hg}$ values are conserved between prey and predators, due to the absence of Hg MIF during trophic transfers or metabolic processes $40,44,48,49$, which reveals MeHg dietary transfers and therefore predator-prey interactions.

Climate change is predicted to increase $\mathrm{MeHg}$ contamination in marine predators, due to increases in seawater temperature and deoxygenation ${ }^{50}$. A proper characterization of trophic MeHg pathways is therefore needed to foresee the evolution of neurotoxicant levels in species, particularly in predators that influence the function of marine ecosystems. In this context, this study sought to evaluate the contribution of different prey groups to MeHg contamination in the white shark. Additionally, our aim was to estimate shark foraging depths and assess the existence of trophic interactions between white sharks and mesopelagic prey. To achieve these objectives, we collected dermis and muscle samples from 95 Northeastern Pacific white sharks in the waters surrounding the aggregation site of Guadalupe Island (Mexico), as well as hair samples from juvenile northern elephant seals, 
91 which are a primary prey of white sharks foraging in this region ${ }^{23,51}$. We measured $\mathrm{Hg}$ 92 isotope signatures from shark and seal samples, and compared those with potential prey for 93 white sharks obtained from published studies in the Central North Pacific ${ }^{30}$ and Northeast 94 Pacific ${ }^{32}$. We used a Bayesian mixing model based on $\mathrm{Hg}$ isotopes to determine both the 95 trophic MeHg sources and the vertical foraging habitat of white sharks. This innovative 96 chemical tracer approach provides an understanding of contaminant exposure, as well as 97 new insights in the trophic ecology of a key marine top predator. 


\section{Materials and methods}

\section{Sample collection}

White sharks $(n=95)$ and northern elephant seals (NES, $n=10)$ were sampled at Guadalupe Island in the Mexican Pacific, between the months of September and November. Shark samples were collected in 2016, 2017 and 2018, and seal samples in 2018. Freeswimming white sharks were attracted with dead baits (Thunnus albacares) near the scientific boat. Samples (dermis and muscle) were taken using a biopsy probe $(1 \mathrm{~cm}$ diameter) targeting the tissue directly below the dorsal fin ${ }^{52}$. The same device was used to collect NES hair on one of the island's beaches. The biopsy probe was cleaned and rinsed with alcohol before and between samples. After collection, tissue samples were immediately transferred to a $-20{ }^{\circ} \mathrm{C}$ freezer onboard the vessel. Individual sharks were sexed (based on the presence or absence of claspers) and sized to the nearest $10 \mathrm{~cm}$ using visual size estimates. White sharks ranged from $2 \mathrm{~m}$ to $5 \mathrm{~m}$ total length (TL) and were composed of juveniles $(<3 \mathrm{~m} \mathrm{TL})$, subadults (3-3.6m TL for males and 3-4.8m TL for females) and adults (> 3.6m TL for males and $>4.8 \mathrm{~m}$ TL for females) ${ }^{53}$ (SI Appendix, Table S3). Samples were collected from different individuals including 54 females, 34 males and 7 unsexed sharks. Dermis and muscle tissues come from different sharks. Sex and maturity stage of seals were visually determined. Most seals were juveniles and subadults (SI Appendix, Table S3).

\section{Mercury analyzes}

Total $\mathrm{Hg}(\mathrm{THg})$ is known to be predominantly in the MeHg form in the dermis and muscle of various shark species ${ }^{46,54-58}$, aquatic and marine mammal hair ${ }^{59-61}$, as well as in pelagic fish muscle and squid mantle ${ }^{30,32}$. THg was thus used as a proxy for $\mathrm{MeHg}$ concentrations in all the species studied here. Moreover, THg isotope ratios in sharks and 
seals analyzed in this work, or obtained in pelagic organisms from previous studies 30,32 , mainly reflect the isotopic signature of $\mathrm{MeHg}$. Consequently, considering that $\mathrm{MeHg}$ (unlike inorganic mercury) is the main $\mathrm{Hg}$ form transferred between prey and predators ${ }^{62,63}$, we refer throughout the text to $\mathrm{MeHg}$, although $\mathrm{MeHg}$ fraction was not measured in our samples.

Blubber and muscle constitute most of the tissues ingested by sharks when eating a seal, and these tissues may have different integration time than hair. However, NES only feed during offshore foraging trips, fasting completely from food and water when at rookeries, such as Guadalupe Island ${ }^{64}$. This onshore fasting implies that MeHg in all seal tissues may come from the same offshore dietary sources ${ }^{65}$. Moreover, as MeHg isotope ratios are similar between different seal tissues fed a constant diet ${ }^{44}$, and $\mathrm{MeHg}$ fraction is high in seal hair ${ }^{60}, \Delta^{199} \mathrm{Hg}$ and $\delta^{202} \mathrm{Hg}$ values of THg in NES hair represent a relevant proxy for MeHg isotopic signature in other tissues (e.g. blubber and muscle) ${ }^{60}$.

\section{- Total Hg concentrations}

Once in the laboratory, samples were lyophilized and homogenized using an electric grinder that was rinsed with alcohol between samples. THg determination was carried out on aliquots (around $10 \mathrm{mg}$ ) of homogenized shark and seal samples by combustion, gold trapping and atomic absorption spectrophotometry detection using a DMA80 analyzer (Milestone, USA). THg concentrations in samples are expressed on a dry weight basis (ng. $\mathrm{g}^{-1}$ dw). Only one analysis was performed per sample, but the accuracy and reproducibility of the method were established using two freeze-dried certified biological material: a tuna fish flesh homogenate reference material (IAEA 436, IRMM) and a lobster hepatopancreas reference material (TORT 3, NRCC). The certified values for IAEA $436\left(4.19 \pm 0.36 \mu \mathrm{g} \cdot \mathrm{g}^{-1} \mathrm{dw}\right.$, 
$\mathrm{n}=10$ ) were reproduced (measured value: $4.33 \pm 0.19 \mu \mathrm{g} \cdot \mathrm{g}^{-1} \mathrm{dw}$ ) within the confidence

146 limits. The certified values for TORT $3\left(0.292 \pm 0.022 \mu \mathrm{g} \cdot \mathrm{g}^{-1} \mathrm{dw}\right)$ were also reproduced

147 (measured value: $0.286 \pm 0.024 \mu \mathrm{g} \cdot \mathrm{g}^{-1} \mathrm{dw}, \mathrm{n}=10$ ) within the confidence limits. The detection $148 \quad$ limit was $0.005 \mu \mathrm{g} \cdot \mathrm{g}^{-1} \mathrm{dw}$. night at room temperature in $3 \mathrm{~mL}$ of concentrated bi-distilled nitric acid $\left(\mathrm{HNO}_{3}\right)$. Samples were then digested on a hotplate for $6 \mathrm{~h}$ at $85^{\circ} \mathrm{C}$ in pyrolyzed glass vessels closed by Teflon caps. One $\mathrm{mL}$ of hydrogen peroxide $\left(\mathrm{H}_{2} \mathrm{O}_{2}\right)$ was added and digestion was continued for another $6 \mathrm{~h}$ at $85^{\circ} \mathrm{C}$. One hundred $\mu \mathrm{L}$ of $\mathrm{BrCl}$ was then added to ensure a full conversion of

MeHg to inorganic $\mathrm{Hg}$. The digest mixtures were finally diluted in an inverse aqua regia (3 types of certified reference materials (NRC TORT-3 and ERM-BCR-464) and blanks were prepared in the same way as tissue samples. Mercury isotope compositions were measured by multi-collector inductively coupled plasma mass spectrometry (MC-ICP-MS, Thermo Finnigan Neptune Plus) with continuous-flow cold vapor (CV) generation using Sn (II) reduction (CETAC HGX-200). Hg isotope composition is expressed in $\delta$ notation and reported in parts per thousand (\%o) deviation from the NIST SRM 3133 standard, which was determined by sample-standard bracketing according to the following equation: $\delta^{\mathrm{XXX}} \mathrm{Hg}(\%$ )

$164=\left[\left(\left({ }^{X X X} \mathrm{Hg} /{ }^{198} \mathrm{Hg}\right)_{\text {sample }} /\left({ }^{\mathrm{XXX}} \mathrm{Hg} /{ }^{198} \mathrm{Hg}\right)_{\text {NIST } 3133}\right)-1\right] \times 1000$ where $\mathrm{XXX}$ represents the mass of each mercury isotope. $\delta^{202} \mathrm{Hg}$ represents $\mathrm{Hg}$ MDF, and $\Delta$ notation is used to express $\mathrm{Hg}$ MIF by the following equation: 
, where $a=0.252,0.502$ and 0.752 for isotopes 199, 200 and 201, respectively.

169

Total $\mathrm{Hg}$ in the diluted solutions was monitored by MC-ICP-MS using ${ }^{202} \mathrm{Hg}$ signals: mean recoveries of $101 \pm 13 \%(n=105)$ for samples and $95 \pm 7 \%(n=16)$ for certified reference materials were found. Hg levels in blanks were below the detection limit. Reproducibility of $\mathrm{Hg}$ isotope measurements was assessed by analyzing UM-Almadén ( $n=20)$, ETH-Fluka ( $n=20)$ and the biological tissue procedural standards NRC TORT-3 $(n=6)$ and ERM-BCR-464 ( $n=10)($ SI Appendix, Table S1). Duplicate analyzes were performed on a subset of 15 shark samples to assess $\delta^{202} \mathrm{Hg}(2 \mathrm{SD}=0.12 \%)$ and $\Delta^{199} \mathrm{Hg}(2 \mathrm{SD}=0.10 \%$ ) long-term reproducibility. Measured isotope signatures as well as analytical reproducibility of standards were found to be in agreement with previously published values ${ }^{30,66-68}$ (SI Appendix, Table S1).

\section{Data treatment}

Two previous studies analyzed $\mathrm{Hg}$ isotopes from pelagic biota in the foraging habitat of Northeast Pacific white sharks (i.e. Central North Pacific ${ }^{30}$ and Northeast Pacific ${ }^{32}$ ) (Figure 1). As $\mathrm{Hg}$ isotope ratios decrease with increasing foraging depth ${ }^{32}$, these potential prey were classified in groups according to their vertical feeding habitat based on individual $\Delta^{199} \mathrm{Hg}$ and $\delta^{202} \mathrm{Hg}$ values (SI Appendix, Table S2), using a K-means cluster analysis ${ }^{69}$. This clustering method delineates groups in the dataset by minimizing the sum of the within-group sums of squared-distances, based on Euclidean distance. The number of groups for the partition was defined using the Caliński-Harabasz criterion ${ }^{70}$. Two groups were identified (SI Appendix, Table S2 and Figure S1): a first with higher $\Delta^{199} \mathrm{Hg}\left(2.69 \pm 0.45 \%\right.$ ) and $\delta^{202} \mathrm{Hg} \quad(0.83 \pm 0.18$ \%) representing epipelagic species (“EPI", $\mathrm{n}=21)$, a second group with lower $\Delta^{199} \mathrm{Hg}(1.60 \pm$ $0.31 \%$ ) and $\delta^{202} \mathrm{Hg}(0.40 \pm 0.24 \%$ ) gathering mesopelagic organisms ("MES", $\mathrm{n}=35)$. These 
groups contain fish and squid species which may be targeted by white sharks or which are representative of a certain foraging depth. As the $\mathrm{Hg}$ isotope signature reflects the feeding depth (i.e. where $\mathrm{Hg}$ is trophically assimilated), the vertical classification of some species may differ from the literature which uses either the median depth of occurrence ${ }^{30}$ or to the depth of maximum occurrence ${ }^{32}$. Flying fish were not included in the analysis since only three individuals from a single species would have formed a fourth group due to outlying $\Delta^{199} \mathrm{Hg}$ and $\delta^{202} \mathrm{Hg}$ values caused by direct proximity with the surface ${ }^{30}$. Crustaceans were excluded because of their low MeHg fraction which could have biased $\mathrm{Hg}$ isotope analyzes ${ }^{32}$, as well as juvenile Pacific bluefin tunas whose signature partially reflect the western Pacific Ocean (outside the white shark distribution) due to recent migration from west to eastern Pacific Ocean waters ${ }^{32}$.

For comparison of $\mathrm{Hg}$ isotope ratios between groups, data were first checked for normality (Shapiro-Wilk tests) and homogeneity of variances (Bartlett tests). One-way analyses of variance (ANOVAs) were applied when these conditions were met, followed by Tukey's HSD tests when more than two groups were compared. In the absence of homoscedasticity Welch's ANOVAs with Games-Howell post hoc test were used. When variables followed a normal distribution, Pearson correlation tests were used to investigate the link between shark length and $\mathrm{Hg}$ isotope ratios. In the absence of normality, Spearman correlation tests were applied. To assess the relationship between $\mathrm{Hg}$ isotope ratios and depth, individual $\Delta^{199} \mathrm{Hg}$ values in potential pelagic prey (i.e. fish and squids from EPI and MES groups, $n=56$ ) were modeled using a logarithmic regression with depth as explanatory variable. Estimated species depths were taken from previous studies ${ }^{30,32}$ and correspond either to the median depth of occurrence ${ }^{30}$ or to the depth of maximum occurrence ${ }^{32}$ (SI Appendix, Table S2). 
Bayesian stable isotope mixing models were constructed with $\Delta^{199} \mathrm{Hg}$ and $\delta^{202} \mathrm{Hg}$ values to estimate the relative contribution of different prey groups to the MeHg burden in white 216 sharks using the "simmr" package ${ }^{71}$ in R. Bayesian approaches use statistical distributions to characterize the uncertainties in food source and consumer isotopic values and in estimated source contributions. Complete formulation of the models is available in the literature ${ }^{72,73}$. Because $\Delta^{199} \mathrm{Hg}$ values are conserved between diet and consumer fish ${ }^{48,49,74}$ and following 220 prior studies ${ }^{32}$, no trophic discrimination factor (TDF) for $\Delta^{199} \mathrm{Hg}$ was incorporated in the models. However, MeHg demethylation has recently been suggested in shark species, 222 leading to an increase in $\delta^{202} \mathrm{Hg}$ values in sharks compared to their prey ${ }^{46}$. Although this $223 \delta^{202} \mathrm{Hg}$ TDF is poorly characterized to date, our models considered different $\delta^{202} \mathrm{Hg}$ TDF ranging from 0 to $1 \%$, based on previous studies on sharks and aquatic mammals $44,46,75,76$.

225 The source data were incorporated in the mean \pm SD form. Models were run with generalist 226 prior distributions and Markov Chain Monte Carlo (MCMC) simulation methods (number of 227 iterations $=100000$, size of burn-in $=10000$, amount of thinning $=100$ and number of MCMC 228 chains $=4)$. Convergence of the models was checked using Gelman-Rubin diagnostics. In all 229 cases, the Gelman-Rubin diagnostic was 1, indicating good convergence.

230 All statistical analyses were performed using the open source software $R$ (version 3.6.2, R 231 Core Team, 2020). 


\section{Results and Discussion}

\section{MeHg exposure during the nearshore season}

In white sharks sampled at Guadalupe Island, $\mathrm{Hg}$ isotope values were higher in dermis $\left(\Delta^{199} \mathrm{Hg}=1.66 \pm 0.22 \%\right.$ ond $\delta^{202} \mathrm{Hg}=1.15 \pm 0.27 \%$ o $)$ compared to muscle $\left(\Delta^{199} \mathrm{Hg}=1.54 \pm\right.$ $0.18 \%$ and $\delta^{202} \mathrm{Hg}=0.88 \pm 0.25 \%$ ) (Figure 2, Figure 3 ). While $\delta^{202} \mathrm{Hg}$ can vary between tissues due to $\mathrm{Hg}$ metabolism ${ }^{76,77}, \Delta^{199} \mathrm{Hg}$ values are not affected by trophic transfer or biological processes, leading to similar $\Delta^{199} \mathrm{Hg}$ values between the different tissues of a consumer with a constant diet $44,48,74,76$. However, $\Delta^{199} \mathrm{Hg}$ values may fluctuate between organs if MeHg exposure changes over time and if tissues exhibit contrasting integration times due to different turnover rates. For instance, arctic seabirds displayed higher $\Delta^{199} \mathrm{Hg}$ values in feathers compared to blood, reflecting seasonal dietary changes and different integration times for MeHg exposure among tissues ${ }^{78}$. In the Northeast Pacific, white sharks are primarily concentrated along the west coast of North America from late summer to early winter while the rest of the year they migrate into oceanic habitats ${ }^{19,24,28,79}$. In aggregation sites such as Guadalupe Island, white sharks have been shown to feed mainly on pinniped species such as sea lions, fur seals and elephant seals ${ }^{21,23}$ while in the open Pacific ocean they are thought to consume pelagic prey ${ }^{79,80}$, even if targeted species remain largely unidentified ${ }^{24,25}$. Using carbon and nitrogen stable isotopes $\left(\delta^{13} \mathrm{C}\right.$ and $\left.\delta^{15} \mathrm{~N}\right)$, previous studies suggested that muscle and dermis have different turnover rates in sharks ${ }^{79,81,82}$. Moreover, dermis $\delta^{13} \mathrm{C}$ and $\delta^{15} \mathrm{~N}$ values of white sharks sampled along the coast of California closely resembled isotopic composition of local pinnipeds, suggesting that dermis displays a faster incorporation rate from prey than muscle tissues, and reflects more recent foraging activity 79. Here, $\Delta^{199} \mathrm{Hg}$ and $\delta^{202} \mathrm{Hg}$ values in white shark tissues were significantly lower than in 
estimated that the NES contribution to shark MeHg exposure was higher in dermis than in muscle (e.g. $46 \%$ versus $25 \%$ without $\delta^{202} \mathrm{Hg}$ TDF, respectively) (Figure 4). In accordance with previous conclusions based on $\delta^{13} \mathrm{C}$ and $\delta^{15} \mathrm{~N}$ values ${ }^{79}, \mathrm{Hg}$ isotopes support the hypothesis of a shorter integration time in dermis compared to muscle, as dermis $\mathrm{Hg}$ isotope values indicate these tissues are more influenced by the recent consumption of pinnipeds at Guadalupe Island. Importantly, these results reveal that seals represent a significant source of MeHg exposure for white sharks during the nearshore season, accounting for half of MeHg in dermis.

\section{MeHg origin at the scale of the entire migration cycle}

Skeletal muscle tissue is believed to integrate dietary MeHg over durations of approximately 1,000 days based on $\Delta^{199} \mathrm{Hg}$ values of captive Pacific bluefin tuna (Thunnus orientalis), which were fed a controlled diet ${ }^{49}$. This slow turnover time, in a metabolically active fish species with similar physiology traits to white sharks ${ }^{83,84}$, enables determining the average origin of MeHg exposure across the entire migratory cycle of white sharks, including both oceanic and coastal seasons. Using muscle $\delta^{13} \mathrm{C}$ and $\delta^{15} \mathrm{~N}$ values, it has been previously suggested that during the coastal season, northeast Pacific white sharks in California have approximately twice the prey consumption rate compared to when they are offshore ${ }^{79}$. Despite previous results suggesting juvenile elephant seals (NES) are one of the main prey for white sharks near pinniped colonies such as Guadalupe Island $21,23,51,85$, their $\mathrm{Hg}$ signature differed significantly from that of sharks (Figure 2, Figure 3). Because $\Delta^{199} \mathrm{Hg}$ values decrease 278 with depth, lower $\Delta^{199} \mathrm{Hg}$ values in white sharks may indicate deeper foraging depths 
mammals and are thought to reflect in vivo demethylation of $\mathrm{MeHg} 44,76,77$, which probably

281

282

283

sets NES apart from other prey groups and white sharks. Consequently, according to Bayesian mixing models based on $\mathrm{Hg}$ isotope tracers, the NES contribution to MeHg levels in shark muscle was estimated to be $25 \%$ maximum (Figure 4B). Lipid reserves represent major sources of metabolic energy in marine predators that have very high energetic requirements related to long migrations ${ }^{86,87}$. To cover energy needs related to undertaking long migrations, white sharks are hypothesized to rely primarily on the blubber of marine mammals during the inshore season ${ }^{86,88,89}$. Indeed, fat can exceed $40 \%$ of the total body mass in juvenile NES ${ }^{64}$, which are believed to be a preferred prey for white sharks due to their high energy supply ${ }^{51,85}$. As MeHg primarily binds to thiol-containing amino acids in proteins ${ }^{90-92}$, blubber which is mainly composed of lipids generally contains low MeHg levels in seals ${ }^{93}$. Thus, despite a presumed high feeding rate during the inshore season ${ }^{79}$, low MeHg levels in pinniped blubber may be responsible for the limited contribution of NES to the global MeHg exposure for white sharks (Figure 4B).

Electronic tags have rapidly increased our knowledge on marine predator movements 94-96 and revealed that many perform large migrations from forage rich coastal realms to offshore oceanic areas traditionally considered deserts ${ }^{20,24}$. Recently, these types of movements have been linked to ocean physics and more specifically to mesoscale eddies, which induce regional penetration of warm surface waters to depths of up to $800 \mathrm{~m}^{26}$. Mesoscale eddies are hypothesized to improve access to deep-sea mesopelagic prey for blue sharks (Prionace glauca) ${ }^{26}$ and white sharks ${ }^{27}$ in the Atlantic Ocean, by releasing them from thermal constraints and reducing the physiological costs of thermoregulation, respectively. Although the twilight zone contains the largest fish biomass in the global ocean ${ }^{29}$, so far there has not been direct evidence of trophic connections between white sharks and 
mesopelagic organisms in the Pacific Ocean. Here, $\Delta^{199} \mathrm{Hg}$ values in white shark tissues were

305 similar to mesopelagic (MES) prey (Figure 2, Figure 3), which we estimated to be the main MeHg source for white sharks, accounting for a minimum of $52 \%$ of dermis $\mathrm{MeHg}$ and $72 \%$ of muscle MeHg (Figure 4A and 4B). These results align with previous observations revealing higher MeHg exposure associated with deeper foraging depths in pelagic fish from the Pacific Ocean ${ }^{31,32}$. Indeed, MeHg concentrations in Pacific waters are known to increase with depth ${ }^{99,100}$, driven by the production of $\mathrm{MeHg}$ below the mixed layer ${ }^{30}$. As $\Delta^{199} \mathrm{Hg}$ values are not modified during MeHg trophic transfer (29-32), our results demonstrate strong evidence that white sharks actively feed on mesopelagic organisms, revealing the existence of trophic interactions that have been suspected for over a decade ${ }^{24,25}$. Finally, $\Delta^{199} \mathrm{Hg}$ values in white shark muscle indicate an exposure to MeHg having undergone weak photochemical degradation in the twilight zone (i.e. low values, Figure 5). As NES are not the main contributor to overall MeHg exposure (Figure 4B), and as white shark distribution during the coastal season is confined bathymetrically primarily to the photic zone (i.e. above $200 \mathrm{~m}$ ) $20,24,28,89$, the low Hg MIF observed in shark tissues strongly suggests a dominant MeHg origin from offshore deep waters. This conclusion is supported by observed diving behaviors in oceanic habitats, where white sharks frequently reached $500 \mathrm{~m}^{20,28}$ and occasionally $1,000 \mathrm{~m}$ $24,27,101$

\section{$\mathrm{Hg}$ isotopes to interpret white shark movements and habitat use}

Contrasting habitat use was previously identified between juvenile and adult white sharks at Guadalupe Island ${ }^{89}$, which could potentially influence MeHg exposure and therefore $\mathrm{Hg}$ isotope signatures. Juvenile white sharks at Guadalupe Island remained close to the shore and in shallow water (i.e. primarily between the surface and $50 \mathrm{~m}$ depth), 
probably to avoid adults patrolling in deeper water (up to $200 \mathrm{~m}$ depth) in search for an opportunity to attack seals ${ }^{89}$. Moreover, juveniles and adults have different thermal 329 preferences, with adults being more tolerant to colder waters, likely due to an increase in 330 thermal inertia and thermoregulatory abilities with ontogeny $89,96,102$. This higher thermal 331 tolerance could result in vertical niche expansion for adult sharks, increasing exposure to $332 \mathrm{MeHg}$ with lower isotope ratios ${ }^{30}$. Although both juvenile and adult sharks were considered 333 in our study (SI Appendix, Table S3), $\Delta^{199} \mathrm{Hg}$ and $\delta^{202} \mathrm{Hg}$ values did not vary with body length 334 for any of the two tissues analyzed (Pearson or Spearman correlation tests, $p>0.05$ ). Thus, our results do not provide support for an effect of habitat use or thermal tolerance on foraging depth, and subsequent MeHg exposure, for white sharks over 2 meters in total length. Alternatively, both juveniles and adult sharks could have access to the same 338 mesopelagic prey that migrate to the surface at night, facilitated by the very steep bathymetry and oceanic nature of Guadalupe Island ${ }^{89}$.

During the seasonal offshore migration, northeast Pacific white sharks occupy a pelagic zone referred to as the "White Shark Café", also known as "Shared Offshore foraging 342 Area" (SOFA), located in the North Pacific Sub-Tropical Gyre halfway between Hawaii and 343 the coasts of Mexico ${ }^{19,24,101}$. The reason why a large number of white sharks congregate in 344 this area remains unanswered, and the two main hypotheses proposed relate to 345 reproduction or feeding 20,28,53. Pronounced sex-based structure in the diving behavior of 346 white sharks has been identified within the Café ${ }^{20}$. If foraging was the only activity, the 347 significant differences in depth occupancy between sexes 20 should be reflected by 348 contrasting $\Delta^{199} \mathrm{Hg}$ values. Indeed, in the Café region, females mainly perform diel vertical 349 migrations (DVM) peaking in the upper 200 meters during the night, while they occupy a 350 water layer between 350 and 500m depth during the day (Figure 5). By contrast, males 
initially exhibit a mix of DVM and rapid oscillatory diving (ROD) behavior, then increasingly focus on ROD at depths between the surface and 200m (day and night), before returning to the coast ${ }^{19,20}$. We found that muscle $\Delta^{199} \mathrm{Hg}$ and $\delta^{202} \mathrm{Hg}$ values did not differ between sexes (ANOVAs, $p>0.05$ ), suggesting no difference in mean foraging depth between females and males at the scale of the entire migration cycle. Only a slight difference in $\Delta^{199} \mathrm{Hg}$ values was found in the more rapidly integrating dermis tissue, with lower values for females compared to males (ANOVA, $p=0.048$ ). Since none of the previous studies has identified differences in diving behavior between males and females at Guadalupe Island ${ }^{24,25,89}$ or along the California coast ${ }^{20,28,103}$, the lower $\Delta^{199} \mathrm{Hg}$ values in the females' dermis likely reflects the fact that females arrive later at Guadalupe Island compared to males ${ }^{24,89}$. At the moment of sample collection, females had spent less time in the insular habitat. Their dermis, which is mainly influenced by recent $\mathrm{MeHg}$ exposure, would therefore reflect to a stronger degree the offshore season, during which both sexes dive deeper and may assimilate MeHg with lower $\Delta^{199} \mathrm{Hg}$ values than in the waters surrounding Guadalupe Island ${ }^{24,25}$. Regarding DVM performed by both sexes, previous studies agree that it may reflect a foraging behavior following the diel vertical migration of the deep scattering layer (DSL), a community of mesopelagic fish and squid that rise near the surface at night and occupy the twilight zone during the day ${ }^{20,25}$. In the Café, the estimated depth at the top of this layer is $460 \mathrm{~m}$ during the day ${ }^{101}$, which corresponds both to the layer occupied by white sharks engaged in daytime DVM ${ }^{20}$ and matches the $\Delta^{199} \mathrm{Hg}$ values found in white shark tissues (Figure 5). The White Shark Café is thought to support considerable mesopelagic biomass ${ }^{53}$. Although DVM is not restricted to the Café and is performed throughout the entire offshore range of white sharks ${ }^{20}$, they may preferentially use this offshore ecosystem to target deep mesopelagic prey, as suggested in other regions ${ }^{27}$. While through ROD behavior males could also target 
375 the DSL which rises to the $200 \mathrm{~m}$ zone at night ${ }^{20}$, daytime ROD appears incompatible with

376 the $\Delta^{199} \mathrm{Hg}$ values found in white shark tissues (e.g. around $1.5 \%$ in muscle), which would

377 correspond to a daytime feeding depth of over 350m (Figure 5). Alternatively, this behavior

378 is similar to the vertical movements of Atlantic Bluefin tuna (Thunnus thynnus) at their

379 breeding grounds ${ }^{104}$ and has previously been proposed as a potential mating activity ${ }^{20,28}$.

380 Overall, $\mathrm{Hg}$ isotopes confirm that mesopelagic foraging occurs in the Café, but do not

381 exclude the possibility that other behaviors such as mating could take place in this area.

In the context of climate change, global warming is expected to expand oxygenminimum zones (OMZs) by reducing oxygen supply to the ocean ${ }^{105,106}$. Microbial MeHg production is enhanced in mesopelagic zones, which are located in sub-thermocline oceanic waters, where oxygen concentration is low and organic matter is intensively remineralized 30,107,108. Thus, the expansion of the MeHg production zone suggests that MeHg exposure could increase for mesopelagic organisms and consequently for their predators such as white sharks. In addition, strong modifications in global mesopelagic biogeographic structure are predicted by the end of this century. More precisely, the mesopelagic biomass is expected to decrease in the North Pacific Tropical Gyre, including the offshore foraging habitat of northeast Pacific white sharks ${ }^{109}$. This study highlights the importance of the mesopelagic compartment in the diet of marine apex predators, such as white sharks. A reduction in the mesopelagic biomass could therefore alter trophic supply to sharks and / or

394 lead to a modification of their migration patterns towards more productive offshore areas, which could alter the location or function of their potential mating area. These climatedriven changes should be carefully considered to avoid potential extinction of white sharks and their ecological roles over the next century ${ }^{6}$. 
Gaël Le Croizier was supported by a postdoctoral grant from the French National Research Institute for Sustainable Development (IRD) and the ISblue "Interdisciplinary graduate School for the blue planet" project (ANR-17-EURE-0015). The project was funded by Alianza WWFTELCEL, The Annemberg Foundation, International Community Foundation, Fins Attached Marine Research and Conservation, The Watermen Project, Pfleger Institute of Environmental Research and Shark Diver. Field work was greatly facilitated through courtesies extended to us by personnel of the University of California, Davis, Centro Interdisciplinario de Ciencias Marinas (CICIMAR), Secretaria de Marina, Comisión de Areas naturals Protegidas (CONANP), Island Conservation (GECl), Horizon Charters, Islander Charters, Solmar V, Club Cantamar and local fishermen from Guadalupe Island. The laboratory analyses were financially supported by the French National Research Agency project ANR-17-CE34-0010 MERTOX (PI David Point). White shark and elephant seal samples were collected under permits from the Secretaría del Medio Ambiente y Recursos Naturales NUM.SGPA/DGVS/06673/17 in 2017 and OFICIO NUM.SGPA/DGVS/004284/18 in 2018.

White shark samples were exported from Mexico under the CITES permit (number MX007) of the Universidad Nacional Autónoma de México and imported in France under the CITES permit (number FR75A) of the Muséum National d'Histoire Naturelle. We thank Laure

417 Laffont and Jérôme Chmeleff for expert management of the OMP mercury and mass spectrometry facilities. Felipe Galvan-Magaña thanks the Instituto Politécnico Nacional (IPN)

419 for the COFAA and EDI fellowships. 


\section{References}

420 (1) Baum, J. K.; Myers, R. A.; Kehler, D. G.; Worm, B.; Harley, S. J.; Doherty, P. A. Collapse and

(2) Myers, R. A.; Worm, B. Rapid Worldwide Depletion of Predatory Fish Communities. Nature 2003, 423 (6937), 280-283. https://doi.org/10.1038/nature01610.

(3) Ferretti, F.; Curnick, D.; Liu, K.; Romanov, E. V.; Block, B. A. Shark Baselines and the Conservation Role of Remote Coral Reef Ecosystems. Science Advances 2018, 4 (3), eaaq0333. https://doi.org/10.1126/sciadv.aaq0333.

(4) Heithaus, M. R.; Frid, A.; Wirsing, A. J.; Worm, B. Predicting Ecological Consequences of Marine Top Predator Declines. Trends in Ecology \& Evolution 2008, 23 (4), 202-210. https://doi.org/10.1016/j.tree.2008.01.003.

(5) Ferretti, F.; Worm, B.; Britten, G. L.; Heithaus, M. R.; Lotze, H. K. Patterns and Ecosystem Consequences of Shark Declines in the Ocean. Ecology Letters 2010, 13 (8), 1055-1071. https://doi.org/10.1111/j.1461-0248.2010.01489.x.

(6) Pimiento, C.; Leprieur, F.; Silvestro, D.; Lefcheck, J. S.; Albouy, C.; Rasher, D. B.; Davis, M.; Svenning, J.-C.; Griffin, J. N. Functional Diversity of Marine Megafauna in the Anthropocene. Science Advances 2020, 6 (16), eaay7650. https://doi.org/10.1126/sciadv.aay7650.

(7) Roff, G.; Brown, C. J.; Priest, M. A.; Mumby, P. J. Decline of Coastal Apex Shark Populations over the Past Half Century. Communications Biology 2018, 1 (1), 223. https://doi.org/10.1038/s42003-018-0233-1.

(8) Hammerschlag, N.; Williams, L.; Fallows, M.; Fallows, C. Disappearance of White Sharks Leads to the Novel Emergence of an Allopatric Apex Predator, the Sevengill Shark. Scientific Reports 2019, 9 (1), 1908. https://doi.org/10.1038/s41598-018-37576-6.

(9) Harrison, A.-L.; Costa, D. P.; Winship, A. J.; Benson, S. R.; Bograd, S. J.; Antolos, M.; Carlisle, A. B.; Dewar, H.; Dutton, P. H.; Jorgensen, S. J.; Kohin, S.; Mate, B. R.; Robinson, P. W.; Schaefer, K. M.; Shaffer, S. A.; Shillinger, G. L.; Simmons, S. E.; Weng, K. C.; Gjerde, K. M.; Block, B. A. The Political Biogeography of Migratory Marine Predators. Nature Ecology \& Evolution 2018, 2 (10), 1571-1578. https://doi.org/10.1038/s41559-018-0646-8.

(10) Horowitz, H. M.; Jacob, D. J.; Zhang, Y.; Dibble, T. S.; Slemr, F.; Amos, H. M.; Schmidt, J. A.; Corbitt, E. S.; Marais, E. A.; Sunderland, E. M. A New Mechanism for Atmospheric Mercury Redox Chemistry: Implications for the Global Mercury Budget. Atmospheric Chemistry and Physics 2017, 17 (10), 6353-6371. https://doi.org/10.5194/acp-17-6353-2017.

(11) Podar, M.; Gilmour, C. C.; Brandt, C. C.; Soren, A.; Brown, S. D.; Crable, B. R.; Palumbo, A. V.; Somenahally, A. C.; Elias, D. A. Global Prevalence and Distribution of Genes and Microorganisms Involved in Mercury Methylation. Science Advances 2015, 1 (9), e1500675. https://doi.org/10.1126/sciadv.1500675.

(12) Eisler, R. Mercury Hazards to Living Organisms; CRC/Taylor \& Francis: Boca Raton, FL, 2006.

(13) Krey, A.; Ostertag, S. K.; Chan, H. M. Assessment of Neurotoxic Effects of Mercury in Beluga Whales (Delphinapterus Leucas), Ringed Seals (Pusa Hispida), and Polar Bears (Ursus Maritimus) from the Canadian Arctic. Science of The Total Environment 2015, 509-510, 237247. https://doi.org/10.1016/j.scitotenv.2014.05.134.

(14) López-Berenguer, G.; Peñalver, J.; Martínez-López, E. A Critical Review about Neurotoxic Effects in Marine Mammals of Mercury and Other Trace Elements. Chemosphere 2020, 246, 125688. https://doi.org/10.1016/j.chemosphere.2019.125688.

(15) Ehnert-Russo, S. L.; Gelsleichter, J. Mercury Accumulation and Effects in the Brain of the Atlantic Sharpnose Shark (Rhizoprionodon Terraenovae). Arch Environ Contam Toxicol 2020, 78 (2), 267-283. https://doi.org/10.1007/s00244-019-00691-0.

(16) McKinney, M. A.; Dean, K.; Hussey, N. E.; Cliff, G.; Wintner, S. P.; Dudley, S. F. J.; Zungu, M. P.; Fisk, A. T. Global versus Local Causes and Health Implications of High Mercury 
Concentrations in Sharks from the East Coast of South Africa. Science of The Total Environment 2016, 541, 176-183. https://doi.org/10.1016/j.scitotenv.2015.09.074.

(17) Huveneers, C.; Apps, K.; Becerril-García, E. E.; Bruce, B.; Butcher, P. A.; Carlisle, A. B.; Chapple, T. K.; Christiansen, H. M.; Cliff, G.; Curtis, T. H.; Daly-Engel, T. S.; Dewar, H.; Dicken, M. L.; Domeier, M. L.; Duffy, C. A. J.; Ford, R.; Francis, M. P.; French, G. C. A.; Galván-Magaña, F.; García-Rodríguez, E.; Gennari, E.; Graham, B.; Hayden, B.; Hoyos-Padilla, E. M.; Hussey, N. E.; Jewell, O. J. D.; Jorgensen, S. J.; Kock, A. A.; Lowe, C. G.; Lyons, K.; Meyer, L.; Oelofse, G.; Oñate-González, E. C.; Oosthuizen, H.; O’Sullivan, J. B.; Ramm, K.; Skomal, G.; Sloan, S.; Smale, M. J.; Sosa-Nishizaki, O.; Sperone, E.; Tamburin, E.; Towner, A. V.; Wcisel, M. A.; Weng, K. C.; Werry, J. M. Future Research Directions on the "Elusive" White Shark. Front. Mar. Sci. 2018, 5. https://doi.org/10.3389/fmars.2018.00455.

(18) Jorgensen, S.; Chapple, T.; Hoyos, M.; Reeb, C.; Block, B. Connectivity among White Shark Coastal Aggregation Areas in the Northeastern Pacific. In Global Perspectives on the Biology and Life History of the White Shark; CRC Press, 2012; pp 159-168.

https://doi.org/10.1201/b11532-16.

(19) Jorgensen, S. J.; Reeb, C. A.; Chapple, T. K.; Anderson, S.; Perle, C.; Sommeran, S. R. V.; FritzCope, C.; Brown, A. C.; Klimley, A. P.; Block, B. A. Philopatry and Migration of Pacific White Sharks. Proceedings of the Royal Society of London B: Biological Sciences 2009, rspb20091155. https://doi.org/10.1098/rspb.2009.1155.

(20) Jorgensen, S. J.; Arnoldi, N. S.; Estess, E. E.; Chapple, T. K.; Rückert, M.; Anderson, S. D.; Block, B. A. Eating or Meeting? Cluster Analysis Reveals Intricacies of White Shark (Carcharodon Carcharias) Migration and Offshore Behavior. PLOS ONE 2012, 7 (10), e47819. https://doi.org/10.1371/journal.pone.0047819.

(21) Long, D.; Roletto, J.; Hanni, K.; Jones, R.; Pyle, P.; Bandar, R. White Shark Predation on Four Pinniped Species in Central California WatersGeographic and Temporal Patterns Inferred from Wounded Carcasses. Great White Sharks 1996, 263-274.

(22) Hammerschlag, N.; Martin, R. A.; Fallows, C. Effects of Environmental Conditions on Predator-Prey Interactions between White Sharks (Carcharodon Carcharias) and Cape Fur Seals (Arctocephalus Pusillus Pusillus) at Seal Island, South Africa. Environ Biol Fish 2006, 76 (2), 341-350. https://doi.org/10.1007/s10641-006-9038-z.

(23) Brown, A. C.; Lee, D. E.; Bradley, R. W.; Anderson, S. Dynamics of White Shark Predation on Pinnipeds in California: Effects of Prey Abundance. Copeia 2010, 2010 (2), 232-238. https://doi.org/10.1643/CE-08-012.

(24) Domeier, M.; Nasby-Lucas, N. Migration Patterns of White Sharks Carcharodon Carcharias Tagged at Guadalupe Island, Mexico, and Identification of an Eastern Pacific Shared Offshore Foraging Area. Marine Ecology Progress Series 2008, 370, 221-237. https://doi.org/10.3354/meps07628.

(25) Nasby-Lucas, N.; Dewar, H.; Lam, C. H.; Goldman, K. J.; Domeier, M. L. White Shark Offshore Habitat: A Behavioral and Environmental Characterization of the Eastern Pacific Shared Offshore Foraging Area. PLOS ONE 2009, 4 (12), e8163.

https://doi.org/10.1371/journal.pone.0008163.

(26) Braun, C. D.; Gaube, P.; Sinclair-Taylor, T. H.; Skomal, G. B.; Thorrold, S. R. Mesoscale Eddies Release Pelagic Sharks from Thermal Constraints to Foraging in the Ocean Twilight Zone. PNAS 2019, 116 (35), 17187-17192. https://doi.org/10.1073/pnas.1903067116.

(27) Gaube, P.; Braun, C. D.; Lawson, G. L.; McGillicuddy, D. J.; Penna, A. D.; Skomal, G. B.; Fischer, C.; Thorrold, S. R. Mesoscale Eddies Influence the Movements of Mature Female White Sharks in the Gulf Stream and Sargasso Sea. Sci Rep 2018, 8 (1), 1-8. https://doi.org/10.1038/s41598-018-25565-8.

(28) Weng, K. C.; Boustany, A. M.; Pyle, P.; Anderson, S. D.; Brown, A.; Block, B. A. Migration and Habitat of White Sharks (Carcharodon Carcharias) in the Eastern Pacific Ocean. Mar Biol 2007, 152 (4), 877-894. https://doi.org/10.1007/s00227-007-0739-4. 
(29) Irigoien, X.; Klevjer, T. A.; Røstad, A.; Martinez, U.; Boyra, G.; Acuña, J. L.; Bode, A.; Echevarria, F.; Gonzalez-Gordillo, J. I.; Hernandez-Leon, S.; Agusti, S.; Aksnes, D. L.; Duarte, C. M.; Kaartvedt, S. Large Mesopelagic Fishes Biomass and Trophic Efficiency in the Open Ocean. Nat Commun 2014, 5 (1), 1-10. https://doi.org/10.1038/ncomms4271.

(30) Blum, J. D.; Popp, B. N.; Drazen, J. C.; Anela Choy, C.; Johnson, M. W. Methylmercury Production below the Mixed Layer in the North Pacific Ocean. Nature Geosci 2013, 6 (10), 879-884. https://doi.org/10.1038/ngeo1918.

(31) Choy, C. A.; Popp, B. N.; Kaneko, J. J.; Drazen, J. C. The Influence of Depth on Mercury Levels in Pelagic Fishes and Their Prey. PNAS 2009, 106 (33), 13865-13869. https://doi.org/10.1073/pnas.0900711106.

(32) Madigan, D. J.; Li, M.; Yin, R.; Baumann, H.; Snodgrass, O. E.; Dewar, H.; Krabbenhoft, D. P.; Baumann, Z.; Fisher, N. S.; Balcom, P.; Sunderland, E. M. Mercury Stable Isotopes Reveal Influence of Foraging Depth on Mercury Concentrations and Growth in Pacific Bluefin Tuna. Environ. Sci. Technol. 2018, 52 (11), 6256-6264. https://doi.org/10.1021/acs.est.7b06429.

(33) Peterson, S. H.; Ackerman, J. T.; Costa, D. P. Marine Foraging Ecology Influences Mercury Bioaccumulation in Deep-Diving Northern Elephant Seals. Proc. R. Soc. B 2015, 282 (1810), 20150710. https://doi.org/10.1098/rspb.2015.0710.

(34) Thompson, D. R.; Furness, R. W.; Monteiro, L. R. Seabirds as Biomonitors of Mercury Inputs to Epipelagic and Mesopelagic Marine Food Chains. Science of The Total Environment 1998, 213 (1-3), 299-305. https://doi.org/10.1016/S0048-9697(98)00103-X.

(35) Peterson, S. H.; Ackerman, J. T.; Crocker, D. E.; Costa, D. P. Foraging and Fasting Can Influence Contaminant Concentrations in Animals: An Example with Mercury Contamination in a Free-Ranging Marine Mammal. Proceedings of the Royal Society B: Biological Sciences 2018, 285 (1872), 20172782. https://doi.org/10.1098/rspb.2017.2782.

(36) Ferriss, B. E.; Essington, T. E. Does Trophic Structure Dictate Mercury Concentrations in Top Predators? A Comparative Analysis of Pelagic Food Webs in the Pacific Ocean. Ecological Modelling 2014, 278, 18-28. https://doi.org/10.1016/j.ecolmodel.2014.01.029.

(37) Houssard, P.; Point, D.; Tremblay-Boyer, L.; Allain, V.; Pethybridge, H.; Masbou, J.; Ferriss, B. E.; Baya, P. A.; Lagane, C.; Menkes, C. E.; Letourneur, Y.; Lorrain, A. A Model of Mercury Distribution in Tuna from the Western and Central Pacific Ocean: Influence of Physiology, Ecology and Environmental Factors. Environ. Sci. Technol. 2019, 53 (3), 1422-1431. https://doi.org/10.1021/acs.est.8b06058.

(38) Monteiro, L.; Costa, V.; Furness, R.; Santos, R. Mercury Concentrations in Prey Fish Indicate Enhanced Bioaccumulation in Mesopelagic Environments. Mar. Ecol. Prog. Ser. 1996, 141, 21-25. https://doi.org/10.3354/meps141021.

(39) Sackett, D. K.; Drazen, J. C.; Choy, C. A.; Popp, B.; Pitz, G. L. Mercury Sources and Trophic Ecology for Hawaiian Bottomfish. Environ. Sci. Technol. 2015, 49 (11), 6909-6918. https://doi.org/10.1021/acs.est.5b01009.

(40) Masbou, J.; Sonke, J. E.; Amouroux, D.; Guillou, G.; Becker, P. R.; Point, D. Hg-Stable Isotope Variations in Marine Top Predators of the Western Arctic Ocean. ACS Earth Space Chem. 2018. https://doi.org/10.1021/acsearthspacechem.8b00017.

(41) Cransveld, A.; Amouroux, D.; Tessier, E.; Koutrakis, E.; Ozturk, A. A.; Bettoso, N.; Mieiro, C. L.; Bérail, S.; Barre, J. P. G.; Sturaro, N.; Schnitzler, J.; Das, K. Mercury Stable Isotopes Discriminate Different Populations of European Seabass and Trace Potential Hg Sources around Europe. Environ. Sci. Technol. 2017, 51 (21), 12219-12228. https://doi.org/10.1021/acs.est.7b01307.

(42) Bergquist, B. A.; Blum, J. D. Mass-Dependent and -Independent Fractionation of Hg Isotopes by Photoreduction in Aquatic Systems. Science 2007, 318 (5849), 417-420. https://doi.org/10.1126/science.1148050.

(43) Zheng, W.; Foucher, D.; Hintelmann, H. Mercury Isotope Fractionation during Volatilization of $\mathrm{Hg}(0)$ from Solution into the Gas Phase. Journal of Analytical Atomic Spectrometry 2007, 22 (9), 1097-1104. https://doi.org/10.1039/B705677J. 
(44) Perrot, V.; Masbou, J.; V. Pastukhov, M.; N. Epov, V.; Point, D.; Bérail, S.; R. Becker, P.; E. Sonke, J.; Amouroux, D. Natural Hg Isotopic Composition of Different Hg Compounds in Mammal Tissues as a Proxy for in Vivo Breakdown of Toxic Methylmercury. Metallomics 2016, 8 (2), 170-178. https://doi.org/10.1039/C5MT00286A.

(45) Janssen, S. E.; Schaefer, J. K.; Barkay, T.; Reinfelder, J. R. Fractionation of Mercury Stable Isotopes during Microbial Methylmercury Production by Iron- and Sulfate-Reducing Bacteria. Environ. Sci. Technol. 2016, 50 (15), 8077-8083. https://doi.org/10.1021/acs.est.6b00854.

(46) Le Croizier, G.; Lorrain, A.; Sonke, J. E.; Jaquemet, S.; Schaal, G.; Renedo, M.; Besnard, L.; Cherel, Y.; Point, D. Mercury Isotopes as Tracers of Ecology and Metabolism in Two Sympatric Shark Species. Environmental Pollution 2020, 114931. https://doi.org/10.1016/j.envpol.2020.114931.

(47) Sackett, D. K.; Drazen, J. C.; Popp, B. N.; Choy, C. A.; Blum, J. D.; Johnson, M. W. Carbon, Nitrogen, and Mercury Isotope Evidence for the Biogeochemical History of Mercury in Hawaiian Marine Bottomfish. Environ. Sci. Technol. 2017, 51 (23), 13976-13984. https://doi.org/10.1021/acs.est.7b04893.

(48) Kwon, S. Y.; Blum, J. D.; Carvan, M. J.; Basu, N.; Head, J. A.; Madenjian, C. P.; David, S. R. Absence of Fractionation of Mercury Isotopes during Trophic Transfer of Methylmercury to Freshwater Fish in Captivity. Environ. Sci. Technol. 2012, 46 (14), 7527-7534. https://doi.org/10.1021/es300794q.

(49) Kwon, S. Y.; Blum, J. D.; Madigan, D. J.; Block, B. A.; Popp, B. N. Quantifying Mercury Isotope Dynamics in Captive Pacific Bluefin Tuna (Thunnus Orientalis). Elem Sci Anth 2016, 4 (0). https://doi.org/10.12952/journal.elementa.000088.

(50) Schartup, A. T.; Thackray, C. P.; Qureshi, A.; Dassuncao, C.; Gillespie, K.; Hanke, A.; Sunderland, E. M. Climate Change and Overfishing Increase Neurotoxicant in Marine Predators. Nature 2019, 572 (7771), 648-650. https://doi.org/10.1038/s41586-019-1468-9.

(51) Jorgensen, S. J.; Anderson, S.; Ferretti, F.; Tietz, J. R.; Chapple, T.; Kanive, P.; Bradley, R. W.; Moxley, J. H.; Block, B. A. Killer Whales Redistribute White Shark Foraging Pressure on Seals. Sci Rep 2019, 9 (1), 1-9. https://doi.org/10.1038/s41598-019-39356-2.

(52) Meyer, L.; Fox, A.; Huveneers, C. Simple Biopsy Modification to Collect Muscle Samples from Free-Swimming Sharks. Biological Conservation 2018, 228, 142-147. https://doi.org/10.1016/j.biocon.2018.10.024.

(53) Domeier, M. L. Global Perspectives on the Biology and Life History of the White Shark; CRC Press, 2012.

(54) Matulik, A. G.; Kerstetter, D. W.; Hammerschlag, N.; Divoll, T.; Hammerschmidt, C. R.; Evers, D. C. Bioaccumulation and Biomagnification of Mercury and Methylmercury in Four Sympatric Coastal Sharks in a Protected Subtropical Lagoon. Marine Pollution Bulletin 2017, 116 (1), 357-364. https://doi.org/10.1016/j.marpolbul.2017.01.033.

(55) Pethybridge, H.; Cossa, D.; Butler, E. C. V. Mercury in 16 Demersal Sharks from Southeast Australia: Biotic and Abiotic Sources of Variation and Consumer Health Implications. Marine Environmental Research 2010, 69 (1), 18-26. https://doi.org/10.1016/j.marenvres.2009.07.006.

(56) de Carvalho, G. G. A.; Degaspari, I. A. M.; Branco, V.; Canário, J.; de Amorim, A. F.; Kennedy, V. H.; Ferreira, J. R. Assessment of Total and Organic Mercury Levels in Blue Sharks (Prionace Glauca) from the South and Southeastern Brazilian Coast. Biol Trace Elem Res 2014, 159 (1), 128-134. https://doi.org/10.1007/s12011-014-9995-6.

(57) Bosch, A. C.; O’Neill, B.; Sigge, G. O.; Kerwath, S. E.; Hoffman, L. C. Heavy Metal Accumulation and Toxicity in Smoothhound (Mustelus Mustelus) Shark from Langebaan Lagoon, South Africa. Food Chemistry 2016, 190, 871-878. https://doi.org/10.1016/j.foodchem.2015.06.034.

(58) Nalluri, D.; Baumann, Z.; Abercrombie, D. L.; Chapman, D. D.; Hammerschmidt, C. R.; Fisher, N. S. Methylmercury in Dried Shark Fins and Shark Fin Soup from American Restaurants. 
Science of The Total Environment 2014, 496, 644-648.

https://doi.org/10.1016/j.scitotenv.2014.04.107.

(59) Eccles, K. M.; Littlewood, E. S.; Thomas, P. J.; Chan, H. M. Distribution of Organic and Inorganic Mercury across the Pelts of Canadian River Otter ( Lontra Canadensis). Sci Rep 2019, 9 (1), 1-11. https://doi.org/10.1038/s41598-019-39893-w.

(60) Pinzone, M.; Acquarone, M.; Tessier, E.; Bérail, S.; Amouroux, D.; Das, K. Hg Speciation and Stable Isotopic Composition in Marine Mammals: New Insights and Perspectives. 2019.

(61) Bechshoft, T.; Dyck, M.; St. Pierre, K. A.; Derocher, A. E.; St. Louis, V. The Use of Hair as a Proxy for Total and Methylmercury Burdens in Polar Bear Muscle Tissue. Science of The Total Environment 2019, 686, 1120-1128. https://doi.org/10.1016/j.scitotenv.2019.06.087.

(62) Wang, W.-X.; Wong, R. S. K. Bioaccumulation Kinetics and Exposure Pathways of Inorganic Mercury and Methylmercury in a Marine Fish, the Sweetlips Plectorhinchus Gibbosus. Marine Ecology Progress Series 2003, 261, 257-268. https://doi.org/10.3354/meps261257.

(63) Kehrig, H. A.; Seixas, T. G.; Baêta, A. P.; Malm, O.; Moreira, I. Inorganic and Methylmercury: Do They Transfer along a Tropical Coastal Food Web? Marine Pollution Bulletin 2010, 60 (12), 2350-2356. https://doi.org/10.1016/j.marpolbul.2010.08.010.

(64) Crocker, D. E.; Champagne, C. D.; Fowler, M. A.; Houser, D. S. Adiposity and Fat Metabolism in Lactating and Fasting Northern Elephant Seals. Adv Nutr 2014, 5 (1), 57-64. https://doi.org/10.3945/an.113.004663.

(65) Boeuf, B. J. L.; Morris, P. A.; Blackwell, S. B.; Crocker, D. E.; Costa, D. P. Diving Behavior of Juvenile Northern Elephant Seals. Can. J. Zool. 1996, 74 (9), 1632-1644. https://doi.org/10.1139/z96-181.

(66) Masbou, J.; Point, D.; Sonke, J. E. Application of a Selective Extraction Method for Methylmercury Compound Specific Stable Isotope Analysis (MeHg-CSIA) in Biological Materials. J. Anal. At. Spectrom. 2013, 28 (10), 1620-1628. https://doi.org/10.1039/C3JA50185J.

(67) Jiskra, M.; G. Wiederhold, J.; Skyllberg, U.; Kronberg, R.-M.; Kretzschmar, R. Source Tracing of Natural Organic Matter Bound Mercury in Boreal Forest Runoff with Mercury Stable Isotopes. Environmental Science: Processes \& Impacts 2017, 19 (10), 1235-1248. https://doi.org/10.1039/C7EM00245A.

(68) Li, M.; Schartup, A. T.; Valberg, A. P.; Ewald, J. D.; Krabbenhoft, D. P.; Yin, R.; Balcom, P. H.; Sunderland, E. M. Environmental Origins of Methylmercury Accumulated in Subarctic Estuarine Fish Indicated by Mercury Stable Isotopes. Environ. Sci. Technol. 2016, 50 (21), 11559-11568. https://doi.org/10.1021/acs.est.6b03206.

(69) Hartigan, J. A.; Wong, M. A. Algorithm AS 136: A K-Means Clustering Algorithm. Journal of the Royal Statistical Society. Series C (Applied Statistics) 1979, 28 (1), 100-108. https://doi.org/10.2307/2346830.

(70) Caliński, T.; Harabasz, J. A Dendrite Method for Cluster Analysis. Communications in Statistics 1974, 3 (1), 1-27. https://doi.org/10.1080/03610927408827101.

(71) Parnell, A. C. Simmr: A Stable Isotope Mixing Model. R Package Version 0.3. See Https://CRAN.R-Project.Org/Package=simmr. 2016.

(72) Parnell, A. C.; Phillips, D. L.; Bearhop, S.; Semmens, B. X.; Ward, E. J.; Moore, J. W.; Jackson, A. L.; Grey, J.; Kelly, D. J.; Inger, R. Bayesian Stable Isotope Mixing Models. Environmetrics 2013, 24 (6), 387-399. https://doi.org/10.1002/env.2221.

(73) Stock, B. C.; Jackson, A. L.; Ward, E. J.; Parnell, A. C.; Phillips, D. L.; Semmens, B. X. Analyzing Mixing Systems Using a New Generation of Bayesian Tracer Mixing Models. PeerJ 2018, 6, e5096. https://doi.org/10.7717/peerj.5096.

(74) Feng, C.; Pedrero, Z.; Gentès, S.; Barre, J.; Renedo, M.; Tessier, E.; Berail, S.; Maury-Brachet, R.; Mesmer-Dudons, N.; Baudrimont, M.; Legeay, A.; Maurice, L.; Gonzalez, P.; Amouroux, D. Specific Pathways of Dietary Methylmercury and Inorganic Mercury Determined by Mercury Speciation and Isotopic Composition in Zebrafish (Danio Rerio). Environ. Sci. Technol. 2015, 49 (21), 12984-12993. https://doi.org/10.1021/acs.est.5b03587. 
(75) Perrot, V.; Pastukhov, M. V.; Epov, V. N.; Husted, S.; Donard, O. F. X.; Amouroux, D. Higher Mass-Independent Isotope Fractionation of Methylmercury in the Pelagic Food Web of Lake Baikal (Russia). Environ. Sci. Technol. 2012, 46 (11), 5902-5911. https://doi.org/10.1021/es204572g.

(76) Li, M.; Juang, C. A.; Ewald, J. D.; Yin, R.; Mikkelsen, B.; Krabbenhoft, D. P.; Balcom, P. H.; Dassuncao, C.; Sunderland, E. M. Selenium and Stable Mercury Isotopes Provide New Insights into Mercury Toxicokinetics in Pilot Whales. Science of The Total Environment 2020, 710, 136325. https://doi.org/10.1016/j.scitotenv.2019.136325.

(77) Bolea-Fernández, E.; Rua-Ibarz, A.; Krupp, E.; Feldmann, J.; Vanhaecke, F. High-Precision Isotopic Analysis Sheds New Light on Mercury Metabolism in Long-Finned Pilot Whales (Globicephala Melas). Scientific Reports 2019, 9. https://doi.org/10.1038/s41598-019-43825z.

(78) Renedo, M.; Amouroux, D.; Duval, B.; Carravieri, A.; Tessier, E.; Barre, J.; Bérail, S.; Pedrero, Z.; Cherel, Y.; Bustamante, P. Seabird Tissues As Efficient Biomonitoring Tools for Hg Isotopic Investigations: Implications of Using Blood and Feathers from Chicks and Adults. Environ. Sci. Technol. 2018, 52 (7), 4227-4234. https://doi.org/10.1021/acs.est.8b00422.

(79) Carlisle, A. B.; Kim, S. L.; Semmens, B. X.; Madigan, D. J.; Jorgensen, S. J.; Perle, C. R.; Anderson, S. D.; Chapple, T. K.; Kanive, P. E.; Block, B. A. Using Stable Isotope Analysis to Understand the Migration and Trophic Ecology of Northeastern Pacific White Sharks (Carcharodon Carcharias). PLOS ONE 2012, 7 (2), e30492. https://doi.org/10.1371/journal.pone.0030492.

(80) Jaime-Rivera, M.; Caraveo-Patiño, J.; Hoyos-Padilla, M.; Galván-Magaña, F. Feeding and Migration Habits of White Shark Carcharodon Carcharias (Lamniformes: Lamnidae) from Isla Guadalupe Inferred by Analysis of Stable Isotopes $\Delta 15 \mathrm{~N}$ and $\Delta 13 \mathrm{C}$. Revista de Biología Tropical 2014, 62 (2), 637-647.

(81) Li, Y.; Hussey, N. E.; Zhang, Y. Quantifying Ontogenetic Stable Isotope Variation between Dermis and Muscle Tissue of Two Pelagic Sharks. Aquatic Biology 2016, 25, 53-60. https://doi.org/10.3354/ab00657.

(82) Prebble, C. E. M.; Rohner, C. A.; Pierce, S. J.; Robinson, D. P.; Jaidah, M. Y.; Bach, S. S.; Trueman, C. N. Limited Latitudinal Ranging of Juvenile Whale Sharks in the Western Indian Ocean Suggests the Existence of Regional Management Units. Marine Ecology Progress Series 2018, 601, 167-183. https://doi.org/10.3354/meps12667.

(83) Bernal, D.; Dickson, K. A.; Shadwick, R. E.; Graham, J. B. Review: Analysis of the Evolutionary Convergence for High Performance Swimming in Lamnid Sharks and Tunas. Comparative Biochemistry and Physiology Part A: Molecular \& Integrative Physiology 2001, 129 (2), 695726. https://doi.org/10.1016/S1095-6433(01)00333-6.

(84) Donley, J. M.; Sepulveda, C. A.; Konstantinidis, P.; Gemballa, S.; Shadwick, R. E. Convergent Evolution in Mechanical Design of Lamnid Sharks and Tunas. Nature 2004, 429 (6987), 6165. https://doi.org/10.1038/nature02435.

(85) Klimley, A. P.; Le Boeuf, B. J.; Cantara, K. M.; Richert, J. E.; Davis, S. F.; Van Sommeran, S.; Kelly, J. T. The Hunting Strategy of White Sharks (Carcharodon Carcharias) near a Seal Colony. Marine Biology 2001, 138 (3), 617-636. https://doi.org/10.1007/s002270000489.

(86) Del Raye, G.; Jorgensen, S. J.; Krumhansl, K.; Ezcurra, J. M.; Block, B. A. Travelling Light: White Sharks (Carcharodon Carcharias) Rely on Body Lipid Stores to Power Ocean-Basin Scale Migration. Proceedings of the Royal Society B: Biological Sciences 2013, 280 (1766), 20130836. https://doi.org/10.1098/rspb.2013.0836.

(87) Pethybridge, H. R.; Parrish, C. C.; Bruce, B. D.; Young, J. W.; Nichols, P. D. Lipid, Fatty Acid and Energy Density Profiles of White Sharks: Insights into the Feeding Ecology and Ecophysiology of a Complex Top Predator. PLOS ONE 2014, 9 (5), e97877. https://doi.org/10.1371/journal.pone.0097877. 
(88) Moxley, J. H.; Nicholson, T. E.; Houtan, K. S. V.; Jorgensen, S. J. Non-Trophic Impacts from White Sharks Complicate Population Recovery for Sea Otters. Ecology and Evolution 2019, 9 (11), 6378-6388. https://doi.org/10.1002/ece3.5209.

(89) Hoyos-Padilla, E. M.; Klimley, A. P.; Galván-Magaña, F.; Antoniou, A. Contrasts in the Movements and Habitat Use of Juvenile and Adult White Sharks (Carcharodon Carcharias) at Guadalupe Island, Mexico. Animal Biotelemetry 2016, 4 (1), 14. https://doi.org/10.1186/s40317-016-0106-7.

(90) Thera, J. C.; Kidd, K. A.; Bertolo, R. F.; O'Driscoll, N. J. Tissue Content of Thiol-Containing Amino Acids Predicts Methylmercury in Aquatic Invertebrates. Science of The Total Environment 2019, 688, 567-573. https://doi.org/10.1016/j.scitotenv.2019.06.225.

(91) Lemes, M.; Wang, F. Methylmercury Speciation in Fish Muscle by HPLC-ICP-MS Following Enzymatic Hydrolysis. Journal of Analytical Atomic Spectrometry 2009, 24 (5), 663-668. https://doi.org/10.1039/B819957B.

(92) Harris, H. H.; Pickering, I. J.; George, G. N. The Chemical Form of Mercury in Fish. Science 2003, 301 (5637), 1203-1203. https://doi.org/10.1126/science.1085941.

(93) Gmelch, L.; Hintelmann, H.; Hickie, B.; Kienberger, H.; Stern, G.; Rychlik, M. Risk-Benefit Assessment of Monomethylmercury and Omega-3 Fatty Acid Intake for Ringed Seal Consumption with Particular Emphasis on Vulnerable Populations in the Western Canadian Arctic. Front. Nutr. 2017, 4. https://doi.org/10.3389/fnut.2017.00030.

(94) Block, B. A.; Jonsen, I. D.; Jorgensen, S. J.; Winship, A. J.; Shaffer, S. A.; Bograd, S. J.; Hazen, E. L.; Foley, D. G.; Breed, G. A.; Harrison, A.-L.; Ganong, J. E.; Swithenbank, A.; Castleton, M.; Dewar, H.; Mate, B. R.; Shillinger, G. L.; Schaefer, K. M.; Benson, S. R.; Weise, M. J.; Henry, R. W.; Costa, D. P. Tracking Apex Marine Predator Movements in a Dynamic Ocean. Nature 2011, 475 (7354), 86-90. https://doi.org/10.1038/nature10082.

(95) Hussey, N. E.; Kessel, S. T.; Aarestrup, K.; Cooke, S. J.; Cowley, P. D.; Fisk, A. T.; Harcourt, R. G.; Holland, K. N.; Iverson, S. J.; Kocik, J. F.; Flemming, J. E. M.; Whoriskey, F. G. Aquatic Animal Telemetry: A Panoramic Window into the Underwater World. Science 2015, 348 (6240), 1255642. https://doi.org/10.1126/science.1255642.

(96) Skomal, G. B.; Braun, C. D.; Chisholm, J. H.; Thorrold, S. R. Movements of the White Shark Carcharodon Carcharias in the North Atlantic Ocean. Marine Ecology Progress Series 2017, 580, 1-16. https://doi.org/10.3354/meps12306.

(97) Wang, R.; Cheng, X.; Xu, L.; Chen, J. Mesoscale Eddy Effects on the Subduction of North Pacific Eastern Subtropical Mode Water. Journal of Geophysical Research: Oceans 2020, 125 (5), e2019JC015641. https://doi.org/10.1029/2019JC015641.

(98) Yang, Z.; Luo, Y. Contribution of Mesoscale Eddies to the Subduction and Transport of North Pacific Eastern Subtropical Mode Water. J. Ocean Univ. China 2020, 19 (1), 36-46. https://doi.org/10.1007/s11802-020-4203-0.

(99) Munson, K. M.; Lamborg, C. H.; Swarr, G. J.; Saito, M. A. Mercury Species Concentrations and Fluxes in the Central Tropical Pacific Ocean. Global Biogeochemical Cycles 2015, 29 (5), 656676. https://doi.org/10.1002/2015GB005120.

(100) Sunderland, E. M.; Krabbenhoft, D. P.; Moreau, J. W.; Strode, S. A.; Landing, W. M. Mercury Sources, Distribution, and Bioavailability in the North Pacific Ocean: Insights from Data and Models: MERCURY IN THE NORTH PACIFIC OCEAN. Global Biogeochem. Cycles 2009, 23 (2), n/a-n/a. https://doi.org/10.1029/2008GB003425.

(101) Nasby-Lucas, N.; Dewar, H.; Lam, C. H.; Goldman, K. J.; Domeier, M. L. White Shark Offshore Habitat: A Behavioral and Environmental Characterization of the Eastern Pacific Shared Offshore Foraging Area. PLOS ONE 2009, 4 (12), e8163. https://doi.org/10.1371/journal.pone.0008163.

(102) Dewar, H.; Domeier, M.; Nasby-Lucas, N. Insights into Young of the Year White Shark, Carcharodon Carcharias, Behavior in the Southern California Bight. Environmental Biology of Fishes 2004, 70 (2), 133-143. https://doi.org/10.1023/B:EBFI.0000029343.54027.6a. 
(103) Goldman, K. J.; Anderson, S. D. Space Utilization and Swimming Depth of White Sharks, Carcharodon Carcharias, at the South Farallon Islands, Central California. Environmental Biology of Fishes 1999, 56 (4), 351-364. https://doi.org/10.1023/A:1007520931105.

(104) Teo, S. L. H.; Boustany, A.; Dewar, H.; Stokesbury, M. J. W.; Weng, K. C.; Beemer, S.; Seitz, A. C.; Farwell, C. J.; Prince, E. D.; Block, B. A. Annual Migrations, Diving Behavior, and Thermal Biology of Atlantic Bluefin Tuna, Thunnus Thynnus, on Their Gulf of Mexico Breeding Grounds. Mar Biol 2007, 151 (1), 1-18. https://doi.org/10.1007/s00227-006-0447-5.

(105) Deutsch, C.; Berelson, W.; Thunell, R.; Weber, T.; Tems, C.; McManus, J.; Crusius, J.; Ito, T.; Baumgartner, T.; Ferreira, V.; Mey, J.; Geen, A. van. Centennial Changes in North Pacific Anoxia Linked to Tropical Trade Winds. Science 2014, 345 (6197), 665-668. https://doi.org/10.1126/science.1252332.

(106) Stramma, L.; Prince, E. D.; Schmidtko, S.; Luo, J.; Hoolihan, J. P.; Visbeck, M.; Wallace, D. W. R.; Brandt, P.; Körtzinger, A. Expansion of Oxygen Minimum Zones May Reduce Available Habitat for Tropical Pelagic Fishes. Nature Climate Change 2012, 2 (1), 33-37. https://doi.org/10.1038/nclimate1304.

(107) Cossa, D.; Durrieu de Madron, X.; Schäfer, J.; Lanceleur, L.; Guédron, S.; Buscail, R.; Thomas, B.; Castelle, S.; Naudin, J.-J. The Open Sea as the Main Source of Methylmercury in the Water Column of the Gulf of Lions (Northwestern Mediterranean Margin). Geochimica et Cosmochimica Acta 2017, 199, 222-237. https://doi.org/10.1016/j.gca.2016.11.037.

(108) Fitzgerald, W. F.; Lamborg, C. H.; Hammerschmidt, C. R. Marine Biogeochemical Cycling of Mercury. Chem. Rev. 2007, 107 (2), 641-662. https://doi.org/10.1021/cr050353m.

(109) Proud, R.; Cox, M. J.; Brierley, A. S. Biogeography of the Global Ocean's Mesopelagic Zone. Current Biology 2017, 27 (1), 113-119. https://doi.org/10.1016/j.cub.2016.11.003. 


\section{Tables and figures}

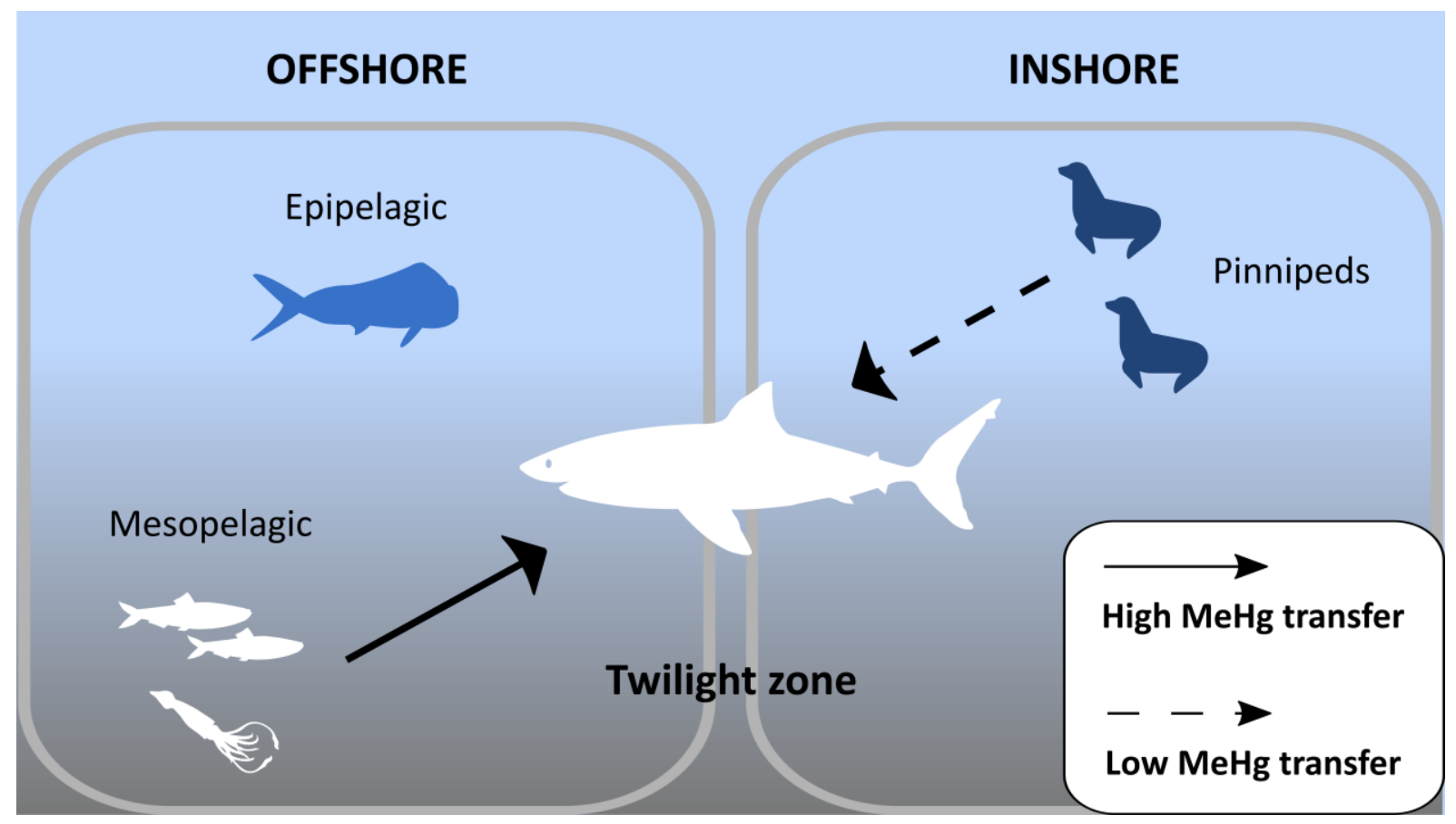

Graphical abstract 


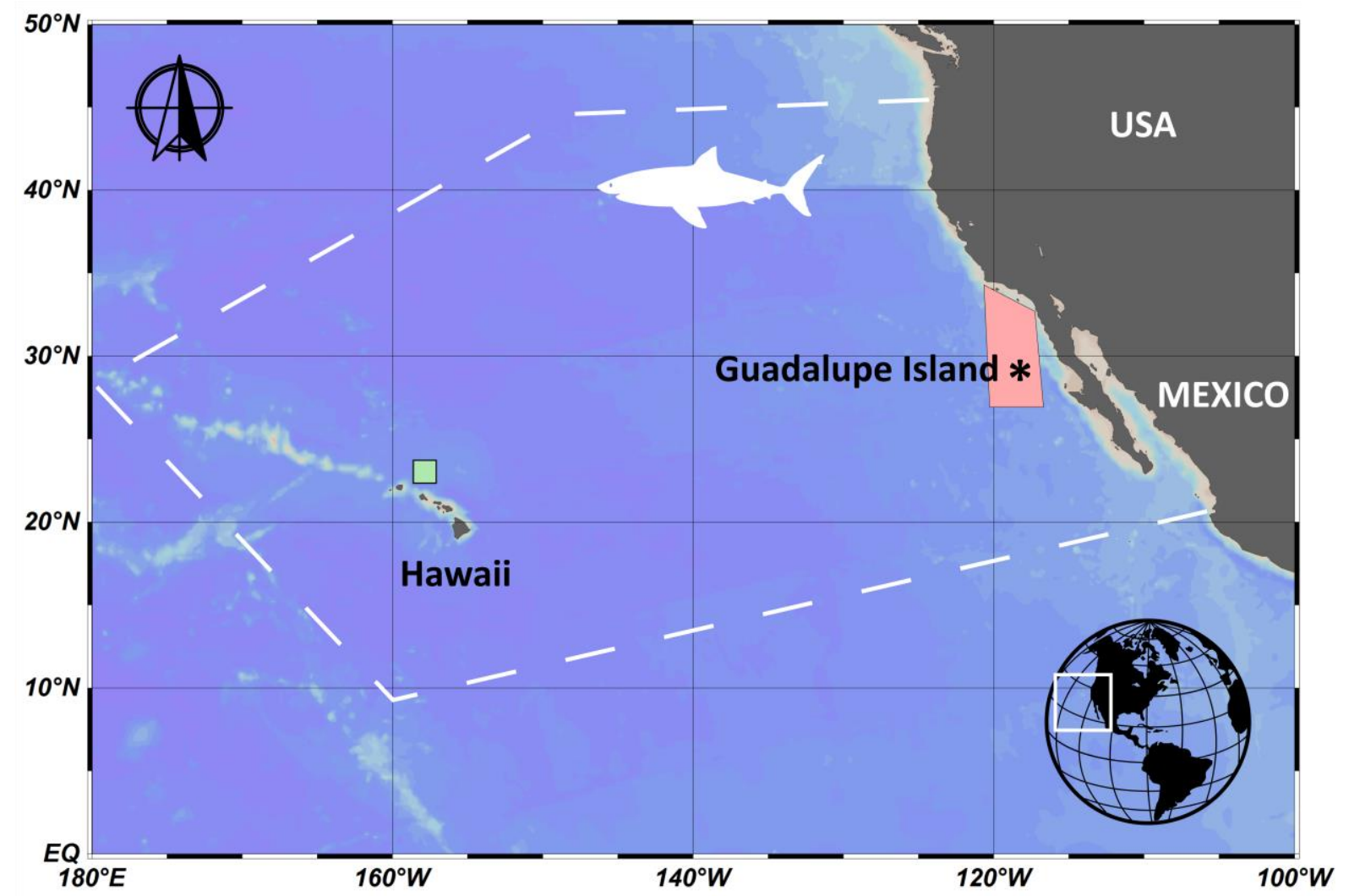

Figure 1: Map of the spatial distribution of white sharks (white hatched lines) in the Northeast Pacific Ocean. White shark and northern elephant seal samples were collected at Guadalupe Island $(*)$ for the present study. $\mathrm{Hg}$ isotope signatures in pelagic organisms were obtained from two previous studies: green and red sampling locations for Blum et al. $(2013)^{30}$ and Madigan et al. $(2018)^{32}$, respectively. 

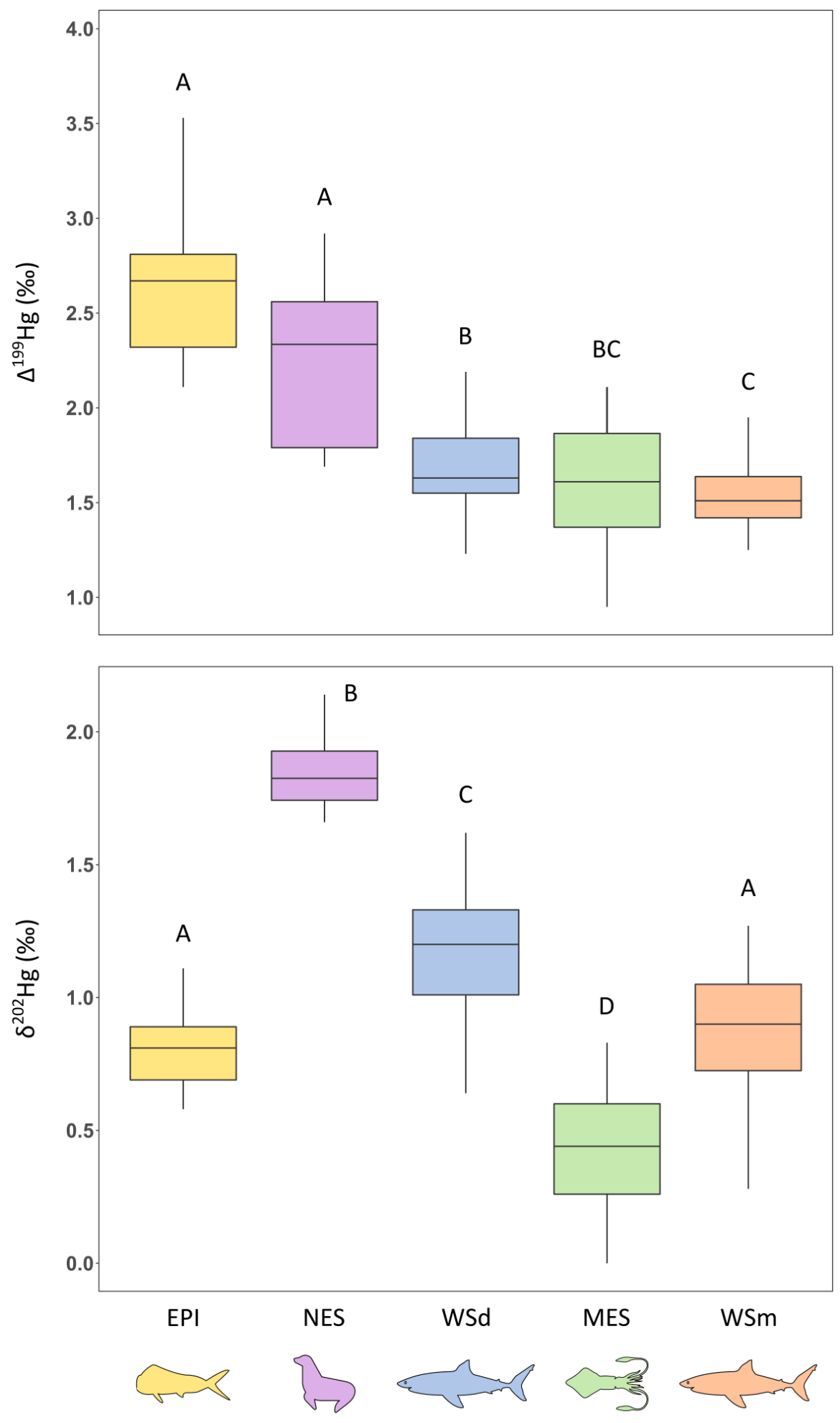

Figure 2: Boxplots of $\mathrm{Hg}$ isotope values in white shark tissues and potential prey groups: epipelagic prey (EPI, $n=21$ ), mesopelagic prey (MES, $n=35$ ), northern elephant seals (NES, $n$ $=10$ ), white shark dermis (WSd, $n=65$ ) and white shark muscle (WSm, $n=30$ ). Groups are ordered by decreasing $\Delta^{199} \mathrm{Hg}$ values. Different letters indicate significant differences between groups ( $\Delta^{199} \mathrm{Hg}$ : Welch's ANOVA with Games-Howell post hoc test, $\delta^{202} \mathrm{Hg}$ : ANOVA followed by Tukey's HSD test; $p<0.05)$. 


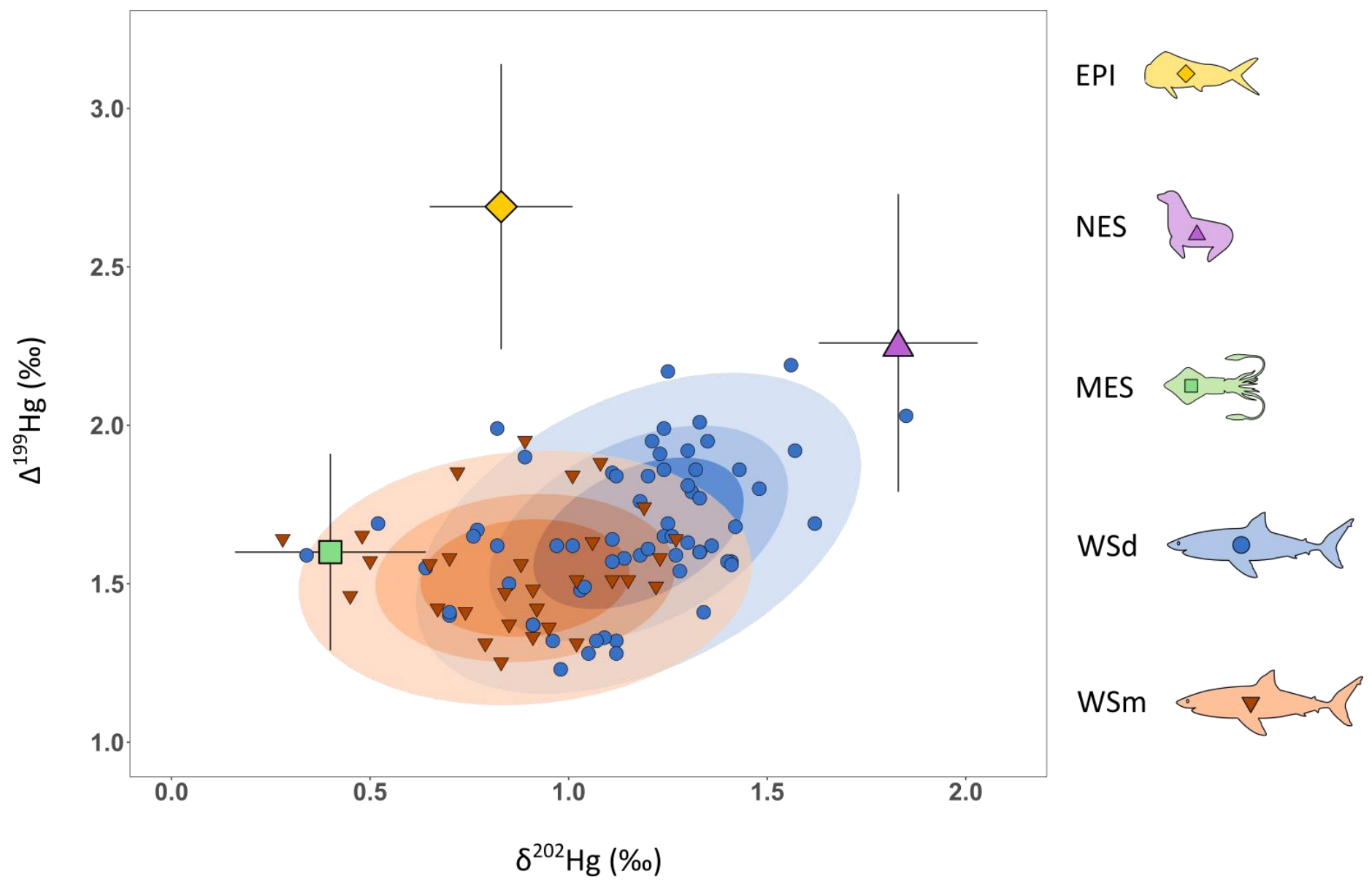

Figure 3: Individual $\Delta^{199} \mathrm{Hg}$ and $\delta^{202} \mathrm{Hg}$ values for white shark dermis (WSd, $\mathrm{n}=65$ ) and muscle (WSm, $n=30$ ). Standard ellipse areas at $50 \%, 75 \%$ and $95 \%$ are figured. $\mathrm{Hg}$ isotope compositions of potential prey groups are displayed as mean ( \pm SD): epipelagic prey $(E P I, n=$ 21), mesopelagic prey (MES, $n=35$ ) and northern elephant seals (NES, $n=10$ ). 


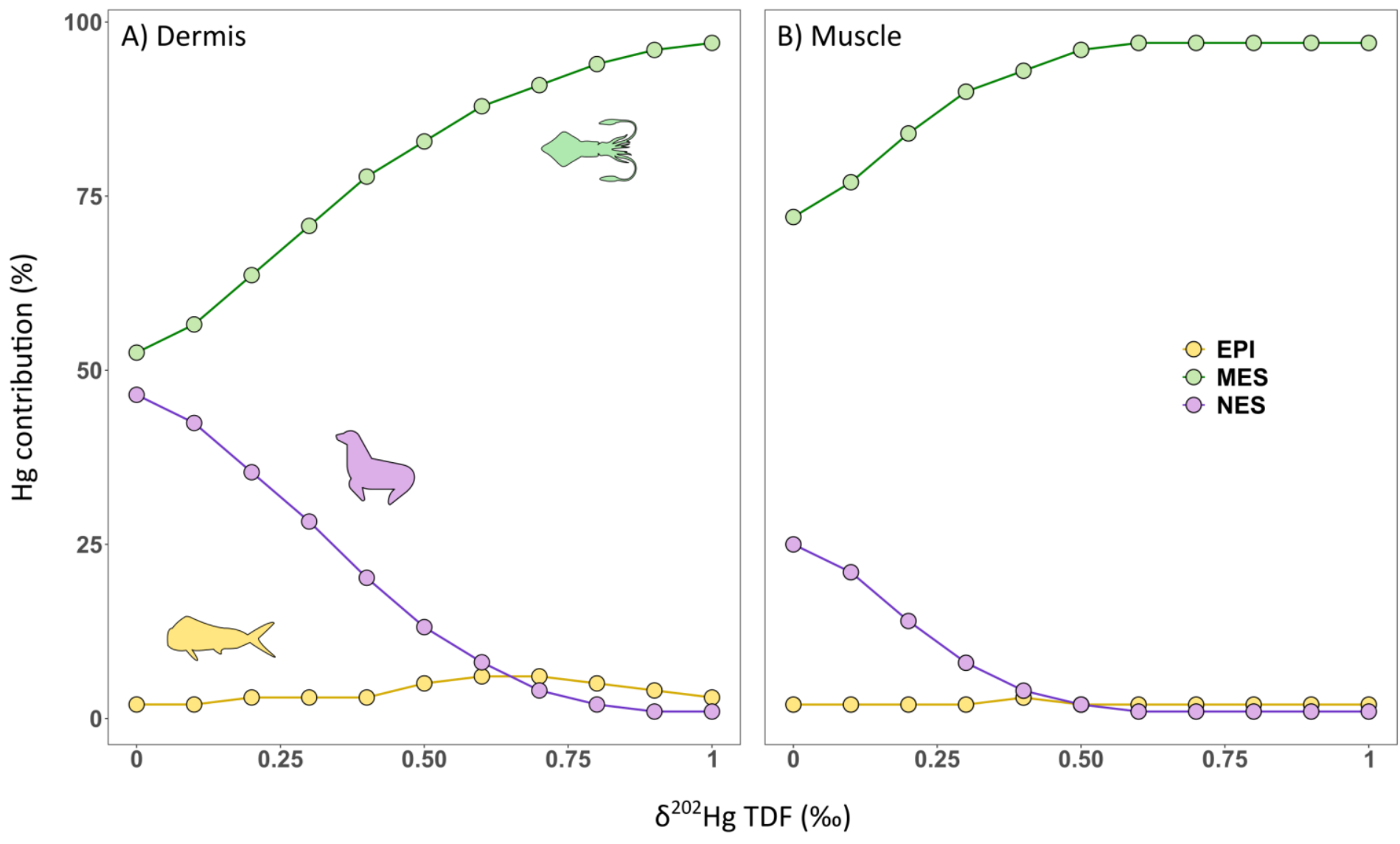

Figure 4: Estimated contributions (\%) based on $\mathrm{Hg}$ isotope values of different prey groups in the $\mathrm{Hg}$ burden in A) dermis and $\mathrm{B}$ ) muscle of white sharks. $\mathrm{Hg}$ contributions were evaluated by considering different trophic discrimination factors (TDF) for $\delta^{202} \mathrm{Hg}$ ranging from 0 to 1 \%. EPI: epipelagic prey; MES: mesopelagic prey; NES: northern elephant seals. Bayesian mixing models indicated a minimum $\mathrm{Hg}$ contribution of $52 \%$ from MES in shark dermis (A) and $72 \%$ in shark muscle (B). Maximum $\mathrm{Hg}$ contribution from NES was $46 \%$ in shark dermis (A) and $25 \%$ in shark muscle (B). Maximum $\mathrm{Hg}$ contribution from EPI was $6 \%$ in shark dermis $(A)$ and $3 \%$ in shark muscle (B). 


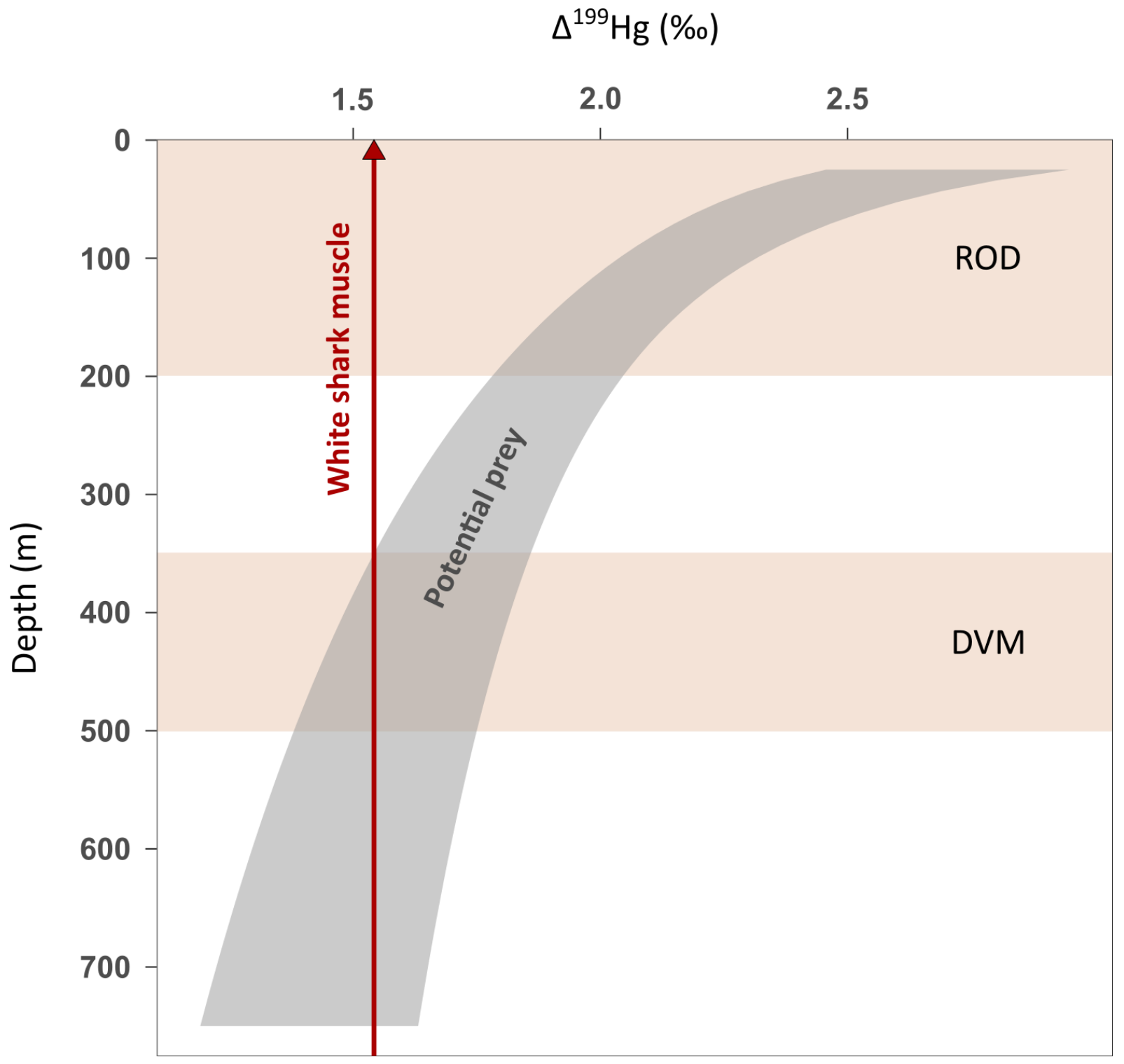

Figure 5: Mean $\Delta^{199} \mathrm{Hg}$ value in white shark muscle from this study $\left(\Delta^{199} \mathrm{Hg}=1.54 \%, \mathrm{n}=30\right.$, red vertical line) and $95 \%$ confidence interval (grey band) from a logarithmic model fitted to $\Delta^{199} \mathrm{Hg}$ values as a function of depth $\left(R^{2}=0.45, p<0.001\right)$ in potential pelagic prey from the literature 30,32 (i.e. fish and squids from epipelagic and mesopelagic groups, $n=56$; $\mathrm{SI}$ Appendix, Table S2). Two offshore diving behaviors of white sharks are figured: the "rapid oscillatory diving" (ROD) behavior occurring between 0 and 200m (day and night) and the daytime "diel vertical migration" (DVM) behavior from 350 to $500 \mathrm{~m}{ }^{20}$. According to the $\Delta^{199} \mathrm{Hg}$ variation in potential prey, the signature of white shark corresponds to a feeding on organisms living over 350 meters deep during the day, which matches daytime DVM but not daytime ROD. 


\section{Supplementary information (SI)}

\section{The twilight zone as a major foraging habitat and mercury source for the}

\section{great white shark.}

Gaël Le Croizier*1, Anne Lorrain², Jeroen E Sonke ${ }^{1}$, Mauricio Hoyos-Padilla*3,4, Felipe GalvánMagaña ${ }^{5}$, Omar Santana-Morales ${ }^{6}$, Marc Aquino-Baleytó ${ }^{3,5}$, Edgar E Becerril-García,3, Gador Muntaner-Lopez ${ }^{3,5}$, Barbara Block ${ }^{7}$, Aaron Carlisle ${ }^{8}$, Salvador Jorgensen ${ }^{9}$, Lucien Besnard ${ }^{2}$, Armelle Jung ${ }^{10}$, Gauthier Schaal ${ }^{2}$, David Point ${ }^{1}$.

${ }^{1}$ UMR Géosciences Environnement Toulouse (GET), Observatoire Midi Pyrénées (OMP), 14 avenue Edouard Belin, 31400 Toulouse, France

${ }^{2}$ Laboratoire des Sciences de I'Environnement Marin (LEMAR), UMR 6539 CNRS/UBO/IRD/IFREMER, BP 70, 29280 Plouzané, France

${ }^{3}$ Pelagios-Kakunjá A.C. Sinaloa 1540. Col. Las Garzas. C.P. 23070. La Paz, B.C.S., México

${ }^{4}$ Fins Attached: Marine Research and Conservation 19675 Still Glen Drive Colorado Springs, CO 80908, USA

${ }^{5}$ Instituto Politécnico Nacional. Centro Interdisciplinario de Ciencias Marinas. Av. IPN s/n., C.P. 23096, La Paz, Baja California Sur, México

${ }^{6}$ ECOCIMATI A.C., 22800, Ensenada, Baja California, Mexico

${ }^{7}$ Hopkins Marine Station, Stanford University, Pacific Grove, CA 93950, USA

${ }^{8}$ School of Marine Science and Policy, University of Delaware, Lewes, DE 19958, USA

${ }^{9}$ University of California Santa Cruz, Institute of Marine Sciences, Santa Cruz, California USA 95064

${ }^{10}$ Des Requins et Des Hommes (DRDH), BLP/Brest-Iroise, 15 rue Dumont d'Urville, Plouzané, 29860, France

Pages: 8

Figures: 1

Tables: 3 


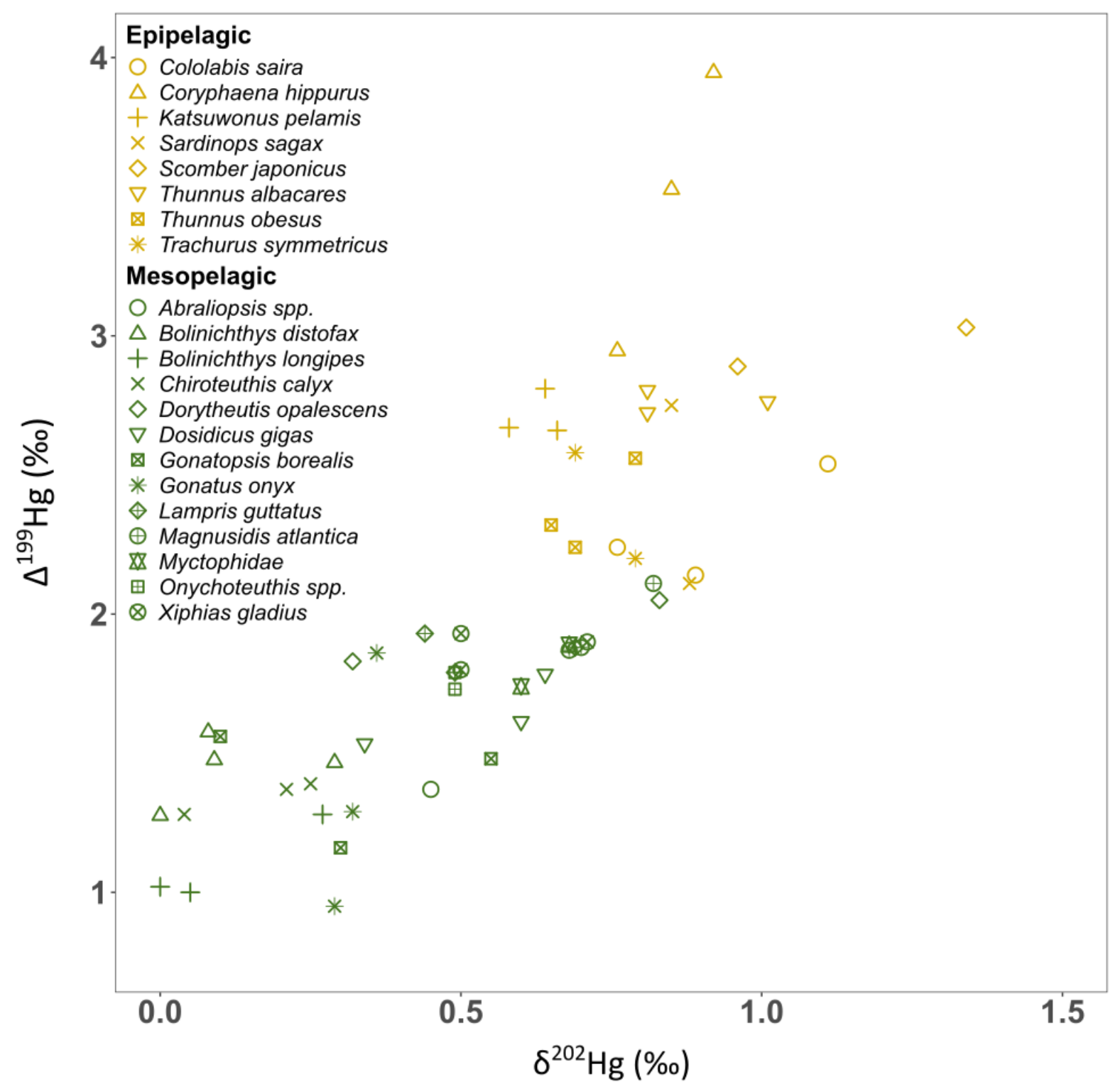

Figure S1: $\mathrm{Hg}$ isotope signatures in pelagic fish and squids from the foraging habitat of northeast Pacific white sharks, obtained in previous studies ${ }^{30,32}$. Species were classified in two groups (i.e. epipelagic or mesopelagic) according to individual $\Delta^{199} \mathrm{Hg}$ and $\delta^{202} \mathrm{Hg}$ values. 
Table S1: Summary (mean $\pm 2 \mathrm{SD}$ ) of $\delta^{202} \mathrm{Hg}$ and $\Delta^{199} \mathrm{Hg}$ values measured in certified reference materials (CRM).

\begin{tabular}{|c|c|c|c|c|}
\hline CRM & n & $\delta^{202} \mathrm{Hg}(\%)$ & $\Delta^{199} \mathrm{Hg}(\%)$ & Reference \\
\hline \multirow{2}{*}{ UM-Almadén } & 20 & $-0.57 \pm 0.10$ & $-0.03 \pm 0.08$ & This study \\
\hline & & $-0.57 \pm 0.05$ & $-0.02 \pm 0.03$ & Blum et al., $2013^{30}$ \\
\hline \multirow{2}{*}{ ETH-Fluka } & 20 & $-1.41 \pm 0.12$ & $0.10 \pm 0.06$ & This study \\
\hline & & $-1.44 \pm 0.12$ & $0.07 \pm 0.05$ & Jiskra et al., $2017^{67}$ \\
\hline \multirow{3}{*}{ BCR 464} & 10 & $0.70 \pm 0.10$ & $2.29 \pm 0.06$ & This study \\
\hline & & $0.73 \pm 0.14$ & $2.29 \pm 0.09$ & Masbou et al., $2013^{66}$ \\
\hline & & $0.69 \pm 0.06$ & $2.40 \pm 0.06$ & Blum et al., $2013^{30}$ \\
\hline \multirow{2}{*}{ TORT 3} & 6 & $0.09 \pm 0.16$ & $0.65 \pm 0.06$ & This study \\
\hline & & $0.13 \pm 0.12$ & $0.69 \pm 0.10$ & Li et al., $2016^{68}$ \\
\hline
\end{tabular}


Table S2: $\mathrm{Hg}$ isotope signatures in pelagic fish and squids from the foraging habitat of northeast Pacific white sharks, obtained in previous studies ${ }^{30,32}$. Species were classified in two groups (i.e. epipelagic or mesopelagic) according to individual $\Delta^{199} \mathrm{Hg}$ and $\delta^{202} \mathrm{Hg}$ values. Estimated species depths of occurrence are presented as described in the literature and correspond either to the median depth of occurrence (Blum et al., 2013) ${ }^{30}$ or to the depth of maximum occurrence (Madigan et al., 2018) 32. " $n$ " refers to the number of individuals per species or group.

\begin{tabular}{|c|c|c|c|c|c|c|c|c|c|c|}
\hline Common name & Species & Reference & Depth (m) & Species n & Species $\delta^{202} \mathrm{Hg}(\% \circ)$ & Species $\Delta{ }^{199} \mathrm{Hg}(\% \circ)$ & Group & Group n & Group $\delta^{202} \mathrm{Hg}(\%)$ & Group $\Delta^{199} \mathrm{Hg}(\%)$ \\
\hline Common dolphinfish & Coryphaena hippurus & Blum et al., 2013 & 50 & 3 & $0.84 \pm 0.08$ & $3.48 \pm 0.50$ & Epipelagic (EPI) & 21 & $0.83 \pm 0.18$ & $2.69 \pm 0.45$ \\
\hline Chub mackerel & Scomber japonicus & Madigan et al., 2018 & 38 & 2 & $1.15 \pm 0.27$ & $2.96 \pm 0.10$ & Epipelagic (EPI) & & & \\
\hline Yellowfin tuna & Thunnus albacares & Blum et al., 2013 & 50 & 3 & $0.88 \pm 0.12$ & $2.76 \pm 0.04$ & Epipelagic (EPI) & & & \\
\hline Skipjack tuna & Katsuwonus pelamis & Blum et al., 2013 & 150 & 3 & $0.63 \pm 0.04$ & $2.71 \pm 0.08$ & Epipelagic (EPI) & & & \\
\hline South american pilchard & Sardinops sagax & Madigan et al., 2018 & 38 & 2 & $0.87 \pm 0.02$ & $2.43 \pm 0.45$ & Epipelagic (EPI) & & & \\
\hline Jack mackerel & Trachurus symmetricus & Madigan et al., 2018 & 38 & 2 & $0.74 \pm 0.07$ & $2.39 \pm 0.27$ & Epipelagic (EPI) & & & \\
\hline Bigeye tuna & Thunnus obesus & Blum et al., 2013 & 250 & 3 & $0.71 \pm 0.07$ & $2.37 \pm 0.17$ & Epipelagic (EPI) & & & \\
\hline Pacific saury & Cololabis saira & Madigan et al., 2018 & 25 & 3 & $0.92 \pm 0.18$ & $2.31 \pm 0.21$ & Epipelagic (EPI) & & & \\
\hline Barracudina & Magnusidis atlantica & Madigan et al., 2018 & 188 & 3 & $0.73 \pm 0.08$ & $1.95 \pm 0.14$ & Mesopelagic (MES) & 35 & $0.40 \pm 0.24$ & $1.60 \pm 0.31$ \\
\hline Opalescent inshore squid & Doryteuthis opalescens & Madigan et al., 2018 & 25 & 2 & $0.58 \pm 0.36$ & $1.94 \pm 0.16$ & Mesopelagic (MES) & & & \\
\hline Swordfish & Xiphias gladius & Blum et al., 2013 & 375 & 3 & $0.57 \pm 0.12$ & $1.88 \pm 0.07$ & Mesopelagic (MES) & & & \\
\hline Opah & Lampris guttatus & Blum et al., 2013 & 225 & 3 & $0.54 \pm 0.13$ & $1.87 \pm 0.07$ & Mesopelagic (MES) & & & \\
\hline Lantern fish & Myctophidae indet. & Madigan et al., 2018 & 63 & 2 & $0.64 \pm 0.06$ & $1.82 \pm 0.11$ & Mesopelagic (MES) & & & \\
\hline Squid & Onychoteuthis spp. & Madigan et al., 2018 & 300 & 2 & $0.49 \pm 0.00$ & $1.76 \pm 0.04$ & Mesopelagic (MES) & & & \\
\hline Humbolt squid & Dosidicus gigas & Madigan et al., 2018 & 80 & 3 & $0.53 \pm 0.16$ & $1.64 \pm 0.13$ & Mesopelagic (MES) & & & \\
\hline Lantern fish & Bolinichthys distofax & Blum et al., 2013 & 590 & 4 & $0.12 \pm 0.12$ & $1.45 \pm 0.13$ & Mesopelagic (MES) & & & \\
\hline Boreopacific armhook squid & Gonatopsis borealis & Madigan et al., 2018 & 550 & 3 & $0.32 \pm 0.23$ & $1.40 \pm 0.21$ & Mesopelagic (MES) & & & \\
\hline Clawed armhook squid & Gonatus onyx & Madigan et al., 2018 & 600 & 3 & $0.32 \pm 0.04$ & $1.37 \pm 0.46$ & Mesopelagic (MES) & & & \\
\hline Squid & Abraliopsis spp. & Madigan et al., 2018 & 450 & 1 & $0.45 \pm 0.00$ & $1.37 \pm 0.00$ & Mesopelagic (MES) & & & \\
\hline Squid & Chiroteuthis calyx & Madigan et al., 2018 & 750 & 3 & $0.17 \pm 0.11$ & $1.35 \pm 0.06$ & Mesopelagic (MES) & & & \\
\hline Lantern fish & Bolinichthys longipes & Blum et al., 2013 & 388 & 3 & $0.11 \pm 0.14$ & $1.10 \pm 0.16$ & Mesopelagic (MES) & & & \\
\hline
\end{tabular}


Table S3: Global data set of the shark and seal samples analyzed in this study.

\begin{tabular}{|c|c|c|c|c|c|c|c|c|c|c|}
\hline Common name & Species & Tissue & Sex & Total length (m) & Size class & THg (ng/g dw) & $\delta^{202} \mathrm{Hg}(\%)$ & $\Delta^{199} \mathrm{Hg}(\% \circ)$ & $\Delta^{200} \mathrm{Hg}(\%)$ & $\Delta^{201} \mathrm{Hg}(\%$ o) \\
\hline Great white shark & Carcharodon carcharias & dermis & M & 2.3 & juvenile & 1072 & 0.96 & 1.32 & 0.08 & 1.05 \\
\hline Great white shark & Carcharodon carcharias & dermis & - & 2.5 & juvenile & 408 & 0.82 & 1.99 & 0.03 & 1.69 \\
\hline Great white shark & Carcharodon carcharias & dermis & $\mathrm{F}$ & 2.5 & juvenile & 941 & 1.18 & 1.59 & 0.03 & 1.44 \\
\hline Great white shark & Carcharodon carcharias & dermis & M & 2.5 & juvenile & 1210 & 0.64 & 1.55 & 0.09 & 1.24 \\
\hline Great white shark & Carcharodon carcharias & dermis & M & 2.5 & juvenile & 1326 & 1.30 & 1.81 & -0.03 & 1.49 \\
\hline Great white shark & Carcharodon carcharias & dermis & $\mathrm{F}$ & 2.5 & juvenile & 335 & 0.91 & 1.37 & 0.10 & 1.25 \\
\hline Great white shark & Carcharodon carcharias & dermis & M & 2.5 & juvenile & 683 & 1.41 & 1.56 & 0.02 & 1.44 \\
\hline Great white shark & Carcharodon carcharias & dermis & $\mathrm{F}$ & 2.5 & juvenile & 103 & 1.12 & 1.32 & 0.04 & 1.16 \\
\hline Great white shark & Carcharodon carcharias & dermis & $M$ & 2.7 & juvenile & 1009 & 1.56 & 2.19 & 0.05 & 1.80 \\
\hline Great white shark & Carcharodon carcharias & dermis & $\mathrm{F}$ & 2.7 & juvenile & 1297 & 1.25 & 1.69 & 0.05 & 1.33 \\
\hline Great white shark & Carcharodon carcharias & dermis & $M$ & 2.8 & juvenile & 846 & 0.77 & 1.67 & 0.06 & 1.47 \\
\hline Great white shark & Carcharodon carcharias & dermis & $\mathrm{F}$ & 3 & subadult & 418 & 0.89 & 1.90 & 0.07 & 1.58 \\
\hline Great white shark & Carcharodon carcharias & dermis & $\mathrm{F}$ & 3 & subadult & 800 & 1.21 & 1.95 & 0.08 & 1.68 \\
\hline Great white shark & Carcharodon carcharias & dermis & $\mathrm{F}$ & 3 & subadult & 820 & 0.34 & 1.59 & 0.10 & 1.24 \\
\hline Great white shark & Carcharodon carcharias & dermis & $\mathrm{F}$ & 3 & subadult & 829 & 0.70 & 1.40 & 0.11 & 1.06 \\
\hline Great white shark & Carcharodon carcharias & dermis & M & 3 & subadult & 901 & 1.20 & 1.61 & 0.02 & 1.33 \\
\hline Great white shark & Carcharodon carcharias & dermis & $\mathrm{F}$ & 3 & subadult & 1471 & 1.05 & 1.28 & 0.04 & 1.12 \\
\hline Great white shark & Carcharodon carcharias & dermis & $\mathrm{F}$ & 3 & subadult & 1637 & 1.43 & 1.86 & 0.10 & 1.55 \\
\hline Great white shark & Carcharodon carcharias & dermis & $M$ & 3 & subadult & 2217 & 1.27 & 1.59 & 0.00 & 1.37 \\
\hline Great white shark & Carcharodon carcharias & dermis & M & 3 & subadult & 2372 & 0.82 & 1.62 & 0.05 & 1.29 \\
\hline Great white shark & Carcharodon carcharias & dermis & $\mathrm{F}$ & 3 & subadult & 285 & 0.91 & 1.37 & 0.01 & 1.18 \\
\hline Great white shark & Carcharodon carcharias & dermis & $\mathrm{F}$ & 3 & subadult & 455 & 1.03 & 1.48 & 0.02 & 1.06 \\
\hline Great white shark & Carcharodon carcharias & dermis & $\mathrm{F}$ & 3.2 & subadult & 842 & 1.24 & 1.99 & 0.08 & 1.63 \\
\hline Great white shark & Carcharodon carcharias & dermis & M & 3.2 & subadult & 1803 & 1.34 & 1.41 & 0.01 & 1.16 \\
\hline Great white shark & Carcharodon carcharias & dermis & $\mathrm{F}$ & 3.2 & subadult & 2210 & 1.24 & 1.65 & 0.04 & 1.42 \\
\hline Great white shark & Carcharodon carcharias & dermis & M & 3.2 & subadult & 2294 & 1.33 & 2.01 & 0.00 & 1.65 \\
\hline
\end{tabular}


Great white shark Great white shark Great white shark Great white shark Great white shark Great white shark Great white shark Great white shark Great white shark Great white shark Great white shark Great white shark Great white shark Great white shark Great white shark Great white shark Great white shark Great white shark Great white shark Great white shark Great white shark Great white shark Great white shark Great white shark Great white shark Great white shark Great white shark Great white shark Great white shark Great white shark Great white shark Great white shark Great white shark Great white shark
Carcharodon carcharias Carcharodon carcharias Carcharodon carcharias Carcharodon carcharias Carcharodon carcharias Carcharodon carcharias Carcharodon carcharias Carcharodon carcharias Carcharodon carcharias Carcharodon carcharias Carcharodon carcharias Carcharodon carcharias Carcharodon carcharias Carcharodon carcharias Carcharodon carcharias Carcharodon carcharias Carcharodon carcharias Carcharodon carcharias Carcharodon carcharias Carcharodon carcharias Carcharodon carcharias Carcharodon carcharias Carcharodon carcharias Carcharodon carcharias Carcharodon carcharias Carcharodon carcharias Carcharodon carcharias Carcharodon carcharias Carcharodon carcharias Carcharodon carcharias Carcharodon carcharias Carcharodon carcharias Carcharodon carcharias Carcharodon carcharias

\begin{tabular}{c|c|} 
dermis & $M$ \\
dermis & $M$ \\
dermis & $F$ \\
dermis & $F$ \\
dermis & $F$ \\
dermis & $M$ \\
dermis & $F$ \\
dermis & $M$ \\
dermis & $F$ \\
dermis & $M$ \\
dermis & $M$ \\
dermis & $F$ \\
dermis & $M$ \\
dermis & $M$ \\
dermis & $M$ \\
dermis & - \\
dermis & $F$ \\
dermis & $M$ \\
dermis & $F$ \\
dermis & $F$ \\
dermis & $M$ \\
dermis & $F$ \\
dermis & $F$ \\
dermis & $F$ \\
dermis & $M$ \\
dermis & $F$ \\
dermis & $F$ \\
dermis & $M$ \\
dermis & $F$ \\
dermis & $M$ \\
dermis & $F$ \\
dermis & $F$ \\
\hline
\end{tabular}

3.2
3.2
3.2
3.2
3.5
3.5
3.5
3.5
3.5
3.5
3.5
3.5
3.5
3.5
3.7
4
4
4
4
4
4
4
4
4
4
4
4
4
4
4
5

subadult
subadult
subadult
subadult
subadult
subadult
subadult
subadult
subadult
subadult
subadult
subadult
subadult
subadult
adult
-
subadult
adult
subadult
subadult
adult
subadult
subadult
subadult
adult
subadult
subadult
adult
subadult
subadult
adult
adult
sula

2813
3914
389
916
654
711
896
920
1180
2098
2129
2504
3074
3366
1197
660
959
980
1198
1308
1544
1726
1882
1921
2095
2098
2123
4361
5135
3135
200
4807
1771
2309

\begin{tabular}{|l}
1.48 \\
1.57 \\
1.41 \\
1.40 \\
1.01 \\
0.52 \\
0.70 \\
1.12 \\
1.28 \\
1.04 \\
0.85 \\
1.18 \\
1.30 \\
1.23 \\
1.32 \\
0.76 \\
1.09 \\
0.97 \\
1.11 \\
1.62 \\
1.25 \\
1.36 \\
1.12 \\
1.07 \\
1.14 \\
1.30 \\
1.24 \\
1.33 \\
1.35 \\
1.26 \\
1.31 \\
1.11 \\
1.42 \\
1.33 \\
\end{tabular}

1.80
1.92
1.57
1.57
1.62
1.69
1.41
1.84
1.54
1.49
1.50
1.76
1.63
1.91
1.86
1.65
1.33
1.62
1.85
1.69
2.17
1.62
1.28
1.32
1.58
1.92
1.86
1.77
1.95
1.65
1.79
1.64
1.68
1.60

\begin{tabular}{l|l}
0.05 & 1.46 \\
0.08 & 1.61 \\
0.05 & 1.23 \\
-0.04 & 1.12 \\
0.06 & 1.45 \\
0.08 & 1.23 \\
0.03 & 1.14 \\
0.10 & 1.56 \\
0.12 & 1.25 \\
0.08 & 1.29 \\
0.04 & 1.21 \\
0.08 & 1.40 \\
0.05 & 1.34 \\
0.10 & 1.63 \\
0.07 & 1.59 \\
0.11 & 1.36 \\
0.02 & 1.06 \\
-0.01 & 1.54 \\
0.06 & 1.55 \\
0.04 & 1.40 \\
0.09 & 1.79 \\
0.10 & 1.33 \\
0.04 & 1.07 \\
0.04 & 1.17 \\
0.04 & 1.39 \\
0.05 & 1.64 \\
0.07 & 1.53 \\
0.05 & 1.47 \\
0.05 & 1.66 \\
0.13 & 1.40 \\
-0.01 & 1.46 \\
0.02 & 1.41 \\
0.01 & 1.41 \\
0.02 & 1.36
\end{tabular}




\begin{tabular}{|c|c|c|c|c|c|c|c|c|c|c|}
\hline Great white shark & Carcharodon carcharias & dermis & $\mathrm{F}$ & 5 & adult & 2508 & 1.33 & 1.60 & 0.03 & 1.26 \\
\hline Great white shark & Carcharodon carcharias & dermis & $\mathrm{F}$ & 5 & adult & 2759 & 0.98 & 1.23 & 0.02 & 1.05 \\
\hline Great white shark & Carcharodon carcharias & dermis & M & 5 & adult & 3326 & 1.85 & 2.03 & 0.11 & 1.71 \\
\hline Great white shark & Carcharodon carcharias & dermis & - & - & - & 2301 & 1.11 & 1.57 & 0.07 & 1.39 \\
\hline Great white shark & Carcharodon carcharias & dermis & - & - & - & 1756 & 1.20 & 1.84 & 0.04 & 1.51 \\
\hline Great white shark & Carcharodon carcharias & muscle & $\mathrm{F}$ & 2 & juvenile & 8688 & 0.88 & 1.56 & 0.04 & 1.28 \\
\hline Great white shark & Carcharodon carcharias & muscle & $\mathrm{F}$ & 2 & juvenile & 7347 & 0.91 & 1.48 & 0.04 & 1.24 \\
\hline Great white shark & Carcharodon carcharias & muscle & $\mathrm{F}$ & 2 & juvenile & 10342 & 0.45 & 1.46 & 0.14 & 1.19 \\
\hline Great white shark & Carcharodon carcharias & muscle & $\mathrm{F}$ & 2 & juvenile & 8631 & 0.67 & 1.42 & 0.13 & 1.11 \\
\hline Great white shark & Carcharodon carcharias & muscle & M & 2 & juvenile & 9642 & 0.72 & 1.85 & 0.00 & 1.42 \\
\hline Great white shark & Carcharodon carcharias & muscle & M & 2 & juvenile & 7606 & 0.84 & 1.47 & 0.08 & 1.24 \\
\hline Great white shark & Carcharodon carcharias & muscle & M & 2.5 & juvenile & 13075 & 1.27 & 1.64 & 0.03 & 1.42 \\
\hline Great white shark & Carcharodon carcharias & muscle & $\mathrm{F}$ & 2.5 & juvenile & 12349 & 0.95 & 1.36 & 0.09 & 1.10 \\
\hline Great white shark & Carcharodon carcharias & muscle & $\mathrm{F}$ & 2.5 & juvenile & 10385 & 0.74 & 1.41 & 0.08 & 1.05 \\
\hline Great white shark & Carcharodon carcharias & muscle & $\mathrm{F}$ & 2.5 & juvenile & 10970 & 0.70 & 1.58 & 0.08 & 1.32 \\
\hline Great white shark & Carcharodon carcharias & muscle & $\mathrm{F}$ & 3 & subadult & 12728 & 0.92 & 1.42 & 0.04 & 1.28 \\
\hline Great white shark & Carcharodon carcharias & muscle & $\mathrm{F}$ & 3 & subadult & 9283 & 1.02 & 1.51 & 0.07 & 1.20 \\
\hline Great white shark & Carcharodon carcharias & muscle & $\mathrm{F}$ & 3 & subadult & 12500 & 0.85 & 1.37 & 0.04 & 1.02 \\
\hline Great white shark & Carcharodon carcharias & muscle & M & 3 & subadult & 13347 & 1.11 & 1.51 & 0.04 & 1.14 \\
\hline Great white shark & Carcharodon carcharias & muscle & $\mathrm{F}$ & 3 & subadult & 8048 & 1.15 & 1.51 & 0.02 & 1.15 \\
\hline Great white shark & Carcharodon carcharias & muscle & $\mathrm{F}$ & 3.2 & subadult & 15719 & 1.23 & 1.58 & 0.03 & 1.38 \\
\hline Great white shark & Carcharodon carcharias & muscle & $\mathrm{F}$ & 3.5 & subadult & 13712 & 0.91 & 1.33 & 0.04 & 1.03 \\
\hline Great white shark & Carcharodon carcharias & muscle & $F$ & 3.5 & subadult & 9767 & 0.89 & 1.95 & 0.02 & 1.52 \\
\hline Great white shark & Carcharodon carcharias & muscle & M & 3.5 & subadult & 14313 & 1.02 & 1.31 & 0.10 & 1.13 \\
\hline Great white shark & Carcharodon carcharias & muscle & M & 3.75 & adult & 14051 & 1.19 & 1.74 & 0.05 & 1.32 \\
\hline Great white shark & Carcharodon carcharias & muscle & $\mathrm{F}$ & 3.75 & subadult & 7342 & 1.06 & 1.63 & 0.11 & 1.52 \\
\hline Great white shark & Carcharodon carcharias & muscle & $M$ & 4 & adult & 10667 & 0.50 & 1.57 & 0.03 & 1.33 \\
\hline Great white shark & Carcharodon carcharias & muscle & - & 4 & - & 6475 & 0.28 & 1.64 & 0.08 & 1.33 \\
\hline Great white shark & Carcharodon carcharias & muscle & $M$ & 4 & adult & 11840 & 0.48 & 1.65 & 0.09 & 1.42 \\
\hline Great white shark & Carcharodon carcharias & muscle & $\mathrm{F}$ & 4 & subadult & 9084 & 1.22 & 1.49 & 0.09 & 1.19 \\
\hline Great white shark & Carcharodon carcharias & muscle & $\mathrm{F}$ & 4.2 & subadult & 11713 & 1.01 & 1.84 & 0.07 & 1.50 \\
\hline Great white shark & Carcharodon carcharias & muscle & $\mathrm{F}$ & 4.5 & subadult & 11950 & 1.08 & 1.88 & 0.06 & 1.53 \\
\hline Great white shark & Carcharodon carcharias & muscle & $\mathrm{F}$ & 5 & adult & 11512 & 0.79 & 1.31 & 0.01 & 1.03 \\
\hline Great white shark & Carcharodon carcharias & muscle & - & - & - & 10311 & 0.65 & 1.56 & 0.08 & 1.26 \\
\hline
\end{tabular}




\begin{tabular}{|c|c|c|c|c|c|c|c|c|c|c|}
\hline Great white shark & Carcharodon carcharias & muscle & - & - & - & 3983 & 0.83 & 1.25 & 0.08 & 1.02 \\
\hline Northern elephant seal & Mirounga angustirostris & hair & $\mathrm{F}$ & - & juvenile & 3802 & 2.05 & 2.18 & 0.09 & 1.82 \\
\hline Northern elephant seal & Mirounga angustirostris & hair & - & - & - & 8969 & 1.79 & 1.77 & 0.07 & 1.47 \\
\hline Northern elephant seal & Mirounga angustirostris & hair & $\mathrm{F}$ & - & subadult & 17943 & 1.93 & 2.92 & 0.11 & 2.59 \\
\hline Northern elephant seal & Mirounga angustirostris & hair & $M$ & - & juvenile & 17939 & 2.14 & 2.82 & 0.02 & 2.47 \\
\hline Northern elephant seal & Mirounga angustirostris & hair & $\mathrm{F}$ & - & subadult & 6138 & 1.86 & 1.76 & 0.05 & 1.40 \\
\hline Northern elephant seal & Mirounga angustirostris & hair & M & - & juvenile & 9042 & 1.75 & 2.58 & 0.10 & 2.32 \\
\hline Northern elephant seal & Mirounga angustirostris & hair & $\mathrm{F}$ & - & subadult & 2378 & 1.74 & 1.85 & 0.02 & 1.44 \\
\hline Northern elephant seal & Mirounga angustirostris & hair & $\mathrm{F}$ & - & adult & 6585 & 1.45 & 1.69 & 0.05 & 1.49 \\
\hline Northern elephant seal & Mirounga angustirostris & hair & $\mathrm{F}$ & - & juvenile & 15227 & 1.66 & 2.50 & 0.07 & 2.24 \\
\hline Northern elephant seal & Mirounga angustirostris & hair & $\mathrm{F}$ & - & juvenile & 22469 & 1.92 & 2.49 & 0.07 & 1.97 \\
\hline
\end{tabular}

